\title{
Mineral composition and organic geochemistry of the Lower Cretaceous Xiagou Formation source rock from the Qingxi Sag, Jiuquan Basin, Northwest China
}

\author{
Gang Gao ${ }^{1} \cdot$ Wei-Wei Zhang ${ }^{1} \cdot$ Guo-Fu $\mathrm{Ma}^{2} \cdot$ Guo Chen ${ }^{1} \cdot$ Tao $^{2} i^{2} \cdot$ Ling-Zhi Hu ${ }^{2} \cdot$ Zhi-Ming Yang $^{2} \cdot$ \\ Jian-Guo Wang ${ }^{2} \cdot$ Jun Yang ${ }^{2}$
}

Received: 16 April 2017 / Published online: 25 January 2018

(C) The Author(s) 2018. This article is an open access publication

\begin{abstract}
The Lower Cretaceous Xiagou Formation contains the major source rocks for the crude oils discovered in the Qingxi Sag and the South Uplift in the Jiuquan Basin, northwestern China. The Xiagou Formation source rock was formed in a closed, anoxic, reducing, alkaline lacustrine environment with a high salinity. Its high content of brittle minerals is favorable for the fracturing of reservoirs in source rock formations in the Qingxi Sag. The Xiagou Formation contains a great number of fair to excellent source rocks, and their organic matter $(\mathrm{OM})$ came chiefly from plankton/algae and high plants as well as possibly bacterial organisms. The Xiagou Formation source rocks mainly contain Type II OM and some Type III and Type I OM, with good oil-generating potential. The source rock maturity is mainly in the early-mature and mature stages, and its $R_{\mathrm{O}}$ value corresponding to oil peak is about $0.8 \%$, which is lower than classic oil peak $R_{\mathrm{O}}$ value of $1.0 \%$; therefore, a great deal of hydrocarbon was generated before the classic oil peak $R_{\mathrm{o}}=1.0 \%$. Mature source rock in the Xiagou Formation tends to be distributed in the older members and at a greater depth. There is a better exploration potential of tight oil in the deep Qingxi Sag.
\end{abstract}

Keywords Mineral composition · Geochemistry $\cdot$ Source rock · Xiagou Formation · Qingxi Sag · Jiuquan Basin

\section{Introduction}

Since the Laojunmiao oilfield was discovered in 1938, the Jiuquan Basin has had a history of oil exploration and development for nearly 80 years (Chen et al. 2001). At present, a great deal of crude oil has been discovered in the Qingxi Sag and the South Uplift, including the Laojunmiao and the Shiyougou oilfields in the South Uplift, and the Qingxi oilfield (including Liugouzhuang and Kulongshan areas) and the Ya'erxia oilfield in the Qingxi Sag (Fan et al. 2004; Zhou et al. 2006; Wang et al. 2008; Li et al. 2010). In

Edited by Jie Hao

Gang Gao

gaogang2819@sina.com

1 State Key Laboratory of Petroleum Resource and Prospecting, China University of Petroleum, Beijing 102249, China

2 Research Institute of Exploration and Development, Yumen Oilfield Company, CNPC, Jiuquan 735019, Gansu, China the South Uplift, oil resources of the Laojunmiao and Shiyougou oilfields are concentrated mainly in the Paleogene; in the Qingxi Sag, oil resources of the Kulongshan and Liugouzhuang fields are concentrated chiefly in the Lower Cretaceous Xiagou Formation and those in the Ya'erxia oilfield are concentrated primarily in the Xiagou Formation, with less in the Paleogene and the Silurian (Xie et al. 2001; Cheng et al. 2007; Zhao et al. 2008; Li et al. 2010). A lot of research into tectonics, sedimentology, reservoir, oil accumulation, and exploration has been undertaken in the Qingxi Sag and the South Uplift (Yang et al. 2004; Wang et al. 2005; Sun et al. 2006; Pan et al. 2007). Previous research indicates that the crude oil in the Qingxi Sag and the South Uplift was chiefly derived from the Xiagou Formation source rock distributed in the Qingxi Sag (Fan et al. 2004; Li et al. 2005; Cheng et al. 2007; Han et al. 2007), but up to now, research into the source rock has been chiefly focused on kerogen geochemistry, thermal evolution, and hydrocarbon-generating kinetics, etc. (Yang et al. 2003; Ma et al. 2009, 2011). With the advancement of oil exploration, there have been more and more crude oil 
resources discovered in the Xiagou Formation and a great amount of source rocks occur within the Qingxi Sag. Current information has revealed that the Xiagou Formation is the major source rock layer in the study area (Fan et al. 2004; Li et al. 2005; Han et al. 2007), but comprehensive research into the detailed geochemistry and hydrocarbon potential of this set of source rocks is scarce. The present study focuses on systematical research into mineral components, abundance, type, maturity of organic matter, and biomarker geochemistry of the source rocks, in order to improve the understanding of the oil exploration potential in the deep sag.

\section{Geological setting}

The Qingxi Sag, which covers an area of $230 \mathrm{~km}^{2}$, is located in the southwest of the West Depression of the Jiuquan Basin (Chen et al. 2001). It is one of the most important hydrocarbon-rich sags in the Jiuquan Basin, and it contains more than 0.16 billion tonnes of proved oil resources. It occupies $76 \%$ of the Western Depression of the Jiuquan Basin (You et al. 2011) (Fig. 1a). The Qingxi Sag is bordered by the Qingxi Low Uplift in the northwest, the Jinta Sag and Yabei Uplift in the northeast, the South Uplift in the southeast, and the Overthrust Nappe Zone in the southwest (Fig. 1a). The basement of the Jiuquan Basin consists of pre-Cretaceous metamorphic rocks (Fig. 1b). In the Qingxi Sag, the sedimentary strata include the Lower Cretaceous Chijinpu $\left(\mathrm{K}_{1} c\right)$, Xiagou $\left(\mathrm{K}_{1} g\right)$, and Zhonggou $\left(\mathrm{K}_{1} z\right)$ Formations, the Paleogene Oligocene, the Neogene Miocene and Pliocene, and Quaternary strata, from oldest to youngest, while in the South Uplift, sedimentary formations only include the Oligocene $\left(\mathrm{E}_{3}\right)$, the Miocene $\left(\mathrm{N}_{1}\right)$, the Pliocene $\left(\mathrm{N}_{2}\right)$, and the Quaternary $(\mathrm{Q})$, from oldest to youngest, without sedimentary strata older than the Oligocene (Wang et al. 2005). In the Qingxi Sag, there are three unconformities between basement and overlying sedimentary strata, between the Zhonggou Formation and Oligocene, and between the Miocene and the Pliocene. In the South Uplift, there are two unconformities between basement and Oligocene, and between the Miocene and the Pliocene (Fig. 1b).

There are three sets of organic matter-rich rocks in the study area, the Chijinpu, the Xiagou, and the Zhonggou Formations, but the Zhonggou Formation rock is not an effective source rock, due to low maturity (Yang et al. 2003). Because of greater burial depth, the rocks in the Xiagou and Chijinpu Formations may become effective source rocks (Ma et al. 2009). The Xiagou Formation is the major source rock for the discovered crude oil (Fan et al. 2004; Ma et al. 2007, 2011). According to the lithologic combination, the Xiagou Formation was divided into four members: the Zeroth $\left(\mathrm{K}_{1} g_{0}\right)$, First $\left(\mathrm{K}_{1} g_{1}\right)$, Second $\left(\mathrm{K}_{1} g_{2}\right)$, and Third $\left(\mathrm{K}_{1} g_{3}\right)$, from oldest to youngest. The Xiagou Formation mainly consists of shale, dolomitic shale, dolomitic sandstone, and sandstone. The shale and dolomitic shale as source rocks generally contain laminas and microfractures as well as minor stylolites (Cheng et al. 2007; Ma et al. 2007). The formation of the source rock which contains carbonates was generally related to saline lacustrine conditions. Generally, this set of source rocks is of high quality, and some of this type of source rocks have been reported globally (Jin et al. 2001; Hudec and Jackson 2006). Because of stronger oil generation and expulsion capacities, the crude oil which comes from the Xiagou Formation source rock was accumulated in the Silurian in the east margin of the Qingxi Sag. These strata overlie the
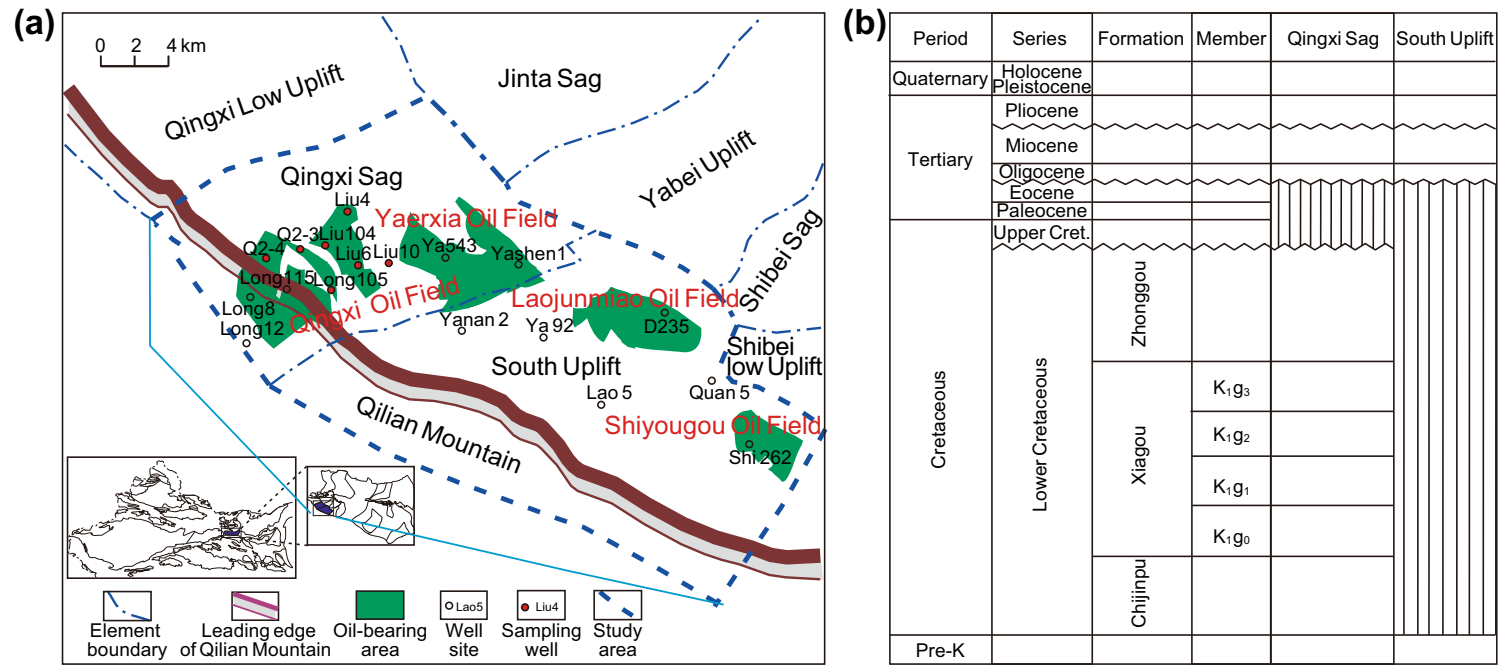

Fig. 1 Sketch map of tectonic location, geological elements (a), and stratigraphic column (b) in the study area 
Table 1 Mineral composition of the Xiagou Formation source rocks of Qingxi Sag, Jiuquan Basin

\begin{tabular}{|c|c|c|c|c|c|c|c|c|c|c|}
\hline Well & Formation & Depth, m & $\mathrm{Q}, \%$ & $\mathrm{PF}, \%$ & $\mathrm{Pl}, \%$ & $\mathrm{Ca}, \%$ & $\mathrm{D}, \%$ & C, $\%$ & Py, \% & A, $\%$ \\
\hline Liu4 & $\mathrm{K}_{1} g_{2}$ & 4448.90 & 4 & 12 & 40 & 0 & 32 & 11 & 1 & 0 \\
\hline Liu4 & $\mathrm{K}_{1} g_{2}$ & 4443.23 & 3 & 14 & 32 & 0 & 41 & 10 & 0 & 0 \\
\hline Liu6 & $\mathrm{K}_{1} g_{2}$ & 4383.70 & 4 & 17 & 40 & 0 & 32 & 3 & 0 & 4 \\
\hline Liu6 & $\mathrm{K}_{1} g_{2}$ & 4383.30 & 7 & 19 & 33 & 0 & 32 & 4 & 5 & 0 \\
\hline Liu104 & $\mathrm{K}_{1} g_{2}$ & 4348.20 & 4 & 10 & 45 & 2 & 23 & 11 & 0 & 5 \\
\hline Liu104 & $\mathrm{K}_{1} g_{2}$ & 4341.80 & 4 & 10 & 40 & 0 & 27 & 11 & 1 & 7 \\
\hline Liu104 & $\mathrm{K}_{1} g_{2}$ & 4343.23 & 3 & 10 & 40 & 0 & 30 & 8 & 4 & 5 \\
\hline Liu104 & $\mathrm{K}_{1} g_{2}$ & 4300.15 & 2 & 0 & 54 & 0 & 31 & 8 & 1 & 4 \\
\hline Liu104 & $\mathrm{K}_{1} g_{2}$ & 4346.40 & 3 & 11 & 42 & 2 & 28 & 7 & 1 & 6 \\
\hline Liu104 & $\mathrm{K}_{1} g_{2}$ & 4301.61 & 2 & 0 & 74 & 0 & 9 & 10 & 0 & 5 \\
\hline Liu104 & $\mathrm{K}_{1} g_{2}$ & 4301.35 & 2 & 0 & 67 & 1 & 15 & 11 & 0 & 4 \\
\hline Liu104 & $\mathrm{K}_{1} g_{2}$ & 4304.88 & 4 & 0 & 67 & 0 & 7 & 15 & 1 & 6 \\
\hline Liu104 & $\mathrm{K}_{1} g_{2}$ & 4342.98 & 5 & 8 & 27 & 0 & 40 & 12 & 3 & 5 \\
\hline Liu104 & $\mathrm{K}_{1} g_{2}$ & 4303.94 & 2 & 3 & 57 & 0 & 20 & 10 & 2 & 6 \\
\hline Liu104 & $\mathrm{K}_{1} g_{2}$ & 4303.16 & 3 & 3 & 70 & 0 & 11 & 4 & 3 & 6 \\
\hline Liu104 & $\mathrm{K}_{1} g_{2}$ & 4302.40 & 2 & 3 & 72 & 1 & 12 & 6 & 0 & 4 \\
\hline Liu104 & $\mathrm{K}_{1} g_{3}$ & 4245.59 & 2 & 2 & 55 & 0 & 22 & 12 & 2 & 5 \\
\hline Liu104 & $\mathrm{K}_{1} g_{3}$ & 4243.90 & 3 & 4 & 54 & 0 & 28 & 3 & 2 & 6 \\
\hline Liu104 & $\mathrm{K}_{1} g_{3}$ & 4242.55 & 2 & 3 & 42 & 0 & 45 & 3 & 0 & 5 \\
\hline Liu104 & $\mathrm{K}_{1} g_{3}$ & 4239.13 & 1 & 2 & 45 & 0 & 38 & 9 & 1 & 4 \\
\hline Liu104 & $\mathrm{K}_{1} g_{3}$ & 4237.02 & 2 & 2 & 45 & 0 & 40 & 5 & 3 & 3 \\
\hline
\end{tabular}

$Q$ Quartz, $P F$ potassium feldspar, $P l$ plagioclase, $C a$ calcite, $D$ dolomite, $C$ clay, $P y$ pyrite, $A$ anhydrite
Xiagou Formation in the Qingxi Sag and the Paleogene in the South Uplift. In the Qingxi Sag, fracture reservoirs are the main oil reservoir type; however, in the South Uplift, structural traps are the chief types for oil accumulation (Chen et al. 2001; Cheng et al. 2007; Wang et al. 2008).

\section{Samples and experiments}

\subsection{Samples}

A total of 37 core samples were collected from the $\mathrm{K}_{1} g_{0}$ (2), $\mathrm{K}_{1} g_{1}$ (14), $\mathrm{K}_{1} g_{2}$ (16), and $\mathrm{K}_{1} g_{3}$ (5) for source rock analyses of the Xiagou Formation. These samples include dolomitic shale and shale from 7 wells (Long105, Q2-3, Q2-4, Liu10, Liu4, Liu6, and Liu104). The locations of the sampling wells are shown in Fig. 1a (left). All of 37 source rock samples were crushed into powder smaller than 80 mesh.

\subsection{Total organic carbon (TOC) and Rock-Eval pyrolysis and bitumen extraction of source rocks}

All of 37 samples were examined as follows: total organic carbon (TOC), Rock-Eval pyrolysis, solvent extraction, and fraction separation. Analyses of TOC were carried out on a Leco CS-230 carbon analyzer. Rock-Eval analysis was performed on an OGE-II rock pyrolyzer which was developed by Experimental Center of Petroleum Geology of China Petroleum Exploration and Development Research Institute, and which can obtain the parameters of $S_{1}$ (mg HC/g Rock), $S_{2}$ (mg HC/g Rock), and $T_{\max }$ (maximum peak temperature of $\left.S_{2},{ }^{\circ} \mathrm{C}\right) .80-100 \mathrm{~g}$ of powder samples (80-100 mesh) was extracted for $72 \mathrm{~h}$ with Soxhlet apparatus and chloroform to obtain solvent extract (bitumen). Fractions of extracts were separated by conventional column chromatography. The extracts were dissolved in excess petroleum ether for $24 \mathrm{~h}$ and then filtered to obtain asphaltene. The soluble remnants were separated with an activated silica gel/alumina chromatography column (Activity I, 80-200 mesh) into saturated, aromatic, and resin fractions by gaseous-solid-phase adsorption chromatography. Hydrocarbon (HC) refers to the saturated plus aromatic fraction of the extract. Extract and hydrocarbon contents are expressed as the percentage content in the rock.

\subsection{GC-MS of source rock saturated fractions}

All of 37 samples were analyzed by gas chromatographymass spectrometry (GC-MS) of the saturated fractions. GC-MS was performed by using an Agilent 7890-5975C gas chromatography-mass spectrometer. The gas 
Table 2 Analytical data for TOC, extract, HC, Rock-Eval pyrolysis, and $R_{\mathrm{O}}$ from the Xiagou Formation source rocks

\begin{tabular}{|c|c|c|c|c|c|c|c|c|c|c|c|c|}
\hline Well & Depth, m & Formation & Lithology & TOC & $S_{1}$ & $S_{2}$ & $S_{1}+S_{2}$ & $T_{\max }$ & $\mathrm{HI}$ & Extract & $\mathrm{HC}$ & $R_{\mathrm{o}}$ \\
\hline Liu 10 & 4898.86 & $\mathrm{~K}_{1} g_{0}$ & Dolomitic shale & 3.22 & 1.57 & 11.31 & 12.88 & 440 & 351 & 0.085 & 0.044 & - \\
\hline Liu 10 & 4903.46 & $\mathrm{~K}_{1} g_{0}$ & Dolomitic shale & 3.39 & 0.94 & 14.27 & 15.21 & 447 & 421 & 0.062 & 0.029 & - \\
\hline Liu 10 & 4706.11 & $\mathrm{~K}_{1} g_{1}$ & Dolomitic shale & 3.35 & 1.36 & 9.92 & 11.28 & 438 & 296 & 0.036 & 0.012 & - \\
\hline Liu 10 & 4704.57 & $\mathrm{~K}_{1} g_{1}$ & Dolomitic shale & 2.52 & 0.37 & 11.34 & 11.71 & 438 & 450 & 0.053 & 0.012 & - \\
\hline Q2-4 & 3910.27 & $\mathrm{~K}_{1} g_{1}$ & Dolomitic shale & 0.38 & 0.08 & 0.70 & 0.78 & 442 & 183 & 0.044 & 0.015 & - \\
\hline Long 105 & 4367.78 & $\mathrm{~K}_{1} g_{1}$ & Dolomitic shale & 1.03 & 0.10 & 3.81 & 3.91 & 437 & 370 & 0.038 & 0.014 & - \\
\hline Q2-4 & 3931.38 & $\mathrm{~K}_{1} g_{1}$ & Dolomitic shale & 0.95 & 0.14 & 1.53 & 1.67 & 439 & 160 & 0.063 & 0.015 & - \\
\hline Q2-4 & 3935.97 & $\mathrm{~K}_{1} g_{1}$ & Dolomitic shale & 0.33 & 0.03 & 0.13 & 0.16 & 448 & 40 & 0.009 & 0.001 & - \\
\hline Long 105 & 4639.32 & $\mathrm{~K}_{1} g_{1}$ & Dolomitic shale & 0.70 & 0.05 & 0.25 & 0.30 & 439 & 36 & 0.032 & 0.008 & - \\
\hline Q2-4 & 4023.91 & $\mathrm{~K}_{1} g_{1}$ & Dolomitic shale & 0.24 & 0.03 & 0.29 & 0.32 & 439 & 123 & 0.013 & 0.005 & - \\
\hline Q2-3 & 4559.43 & $\mathrm{~K}_{1} g_{1}$ & Dolomitic shale & 3.76 & 3.82 & 23.16 & 26.98 & 448 & 616 & 1.046 & 0.601 & 0.70 \\
\hline Q2-3 & 4552.58 & $\mathrm{~K}_{1} g_{1}$ & Dolomitic shale & 2.83 & 2.63 & 13.56 & 16.19 & 444 & 479 & 0.986 & 0.605 & 0.68 \\
\hline Q2-3 & 4558.43 & $\mathrm{~K}_{1} g_{1}$ & Dolomitic shale & 2.33 & 1.36 & 10.38 & 11.74 & 444 & 445 & 0.502 & 0.279 & - \\
\hline Q2-3 & 4553.53 & $\mathrm{~K}_{1} g_{1}$ & Dolomitic shale & 3.42 & 3.36 & 22.25 & 25.61 & 444 & 651 & 1.107 & 0.495 & 0.71 \\
\hline Q2-3 & 4241.80 & $\mathrm{~K}_{1} g_{1}$ & Dolomitic shale & 1.11 & 0.36 & 3.94 & 4.30 & 443 & 355 & 0.150 & 0.075 & 0.66 \\
\hline Q2-3 & 4240.10 & $\mathrm{~K}_{1} g_{1}$ & Dolomitic shale & 0.81 & 0.23 & 2.67 & 2.90 & 445 & 328 & 0.138 & 0.069 & 0.65 \\
\hline Liu4 & 4448.90 & $\mathrm{~K}_{1} g_{2}$ & Dolomitic shale & 2.65 & 0.17 & 16.97 & 17.14 & 445 & 640 & 0.1205 & 0.037 & 0.72 \\
\hline Liu4 & 4443.23 & $\mathrm{~K}_{1} g_{2}$ & Dolomitic shale & 2.41 & 0.23 & 13.65 & 13.88 & 444 & 566 & 0.1400 & 0.043 & - \\
\hline Liu6 & 4383.70 & $\mathrm{~K}_{1} g_{2}$ & Dolomitic shale & 0.51 & 0.10 & 0.66 & 0.76 & 434 & 130 & 0.0591 & 0.018 & - \\
\hline Liu6 & 4383.30 & $\mathrm{~K}_{1} g_{2}$ & Dolomitic shale & 0.98 & 0.27 & 2.25 & 2.52 & 439 & 230 & 0.1391 & 0.055 & 0.68 \\
\hline Liu104 & 4348.20 & $\mathrm{~K}_{1} g_{2}$ & Shale & 1.50 & 0.24 & 4.21 & 4.45 & 440 & 281 & 0.1180 & 0.039 & - \\
\hline Liu104 & 4341.80 & $\mathrm{~K}_{1} g_{2}$ & Dolomitic shale & 1.35 & 0.49 & 3.47 & 3.96 & 438 & 257 & 0.2201 & 0.084 & 0.68 \\
\hline Liu104 & 4343.23 & $\mathrm{~K}_{1} g_{2}$ & Dolomitic shale & 2.24 & 0.41 & 15.43 & 15.84 & 441 & 689 & 0.5550 & 0.093 & 0.68 \\
\hline Liu104 & 4300.15 & $\mathrm{~K}_{1} g_{2}$ & Dolomitic shale & 1.25 & 0.21 & 1.98 & 2.19 & 434 & 158 & 0.0973 & 0.031 & 0.68 \\
\hline Liu104 & 4346.40 & $\mathrm{~K}_{1} g_{2}$ & Dolomitic shale & 1.15 & 0.24 & 2.09 & 2.33 & 438 & 182 & 0.1199 & 0.047 & 0.65 \\
\hline Liu104 & 4301.61 & $\mathrm{~K}_{1} g_{2}$ & Shale & 0.90 & 0.01 & 0.02 & 0.03 & 557 & 2 & 0.1282 & 0.041 & 0.62 \\
\hline Liu104 & 4301.35 & $\mathrm{~K}_{1} g_{2}$ & Shale & 1.25 & 0.34 & 2.74 & 3.08 & 437 & 219 & 0.1381 & 0.070 & - \\
\hline Liu104 & 4304.88 & $\mathrm{~K}_{1} g_{2}$ & Shale & 2.06 & 0.64 & 15.99 & 16.63 & 444 & 776 & 0.2013 & 0.091 & 0.63 \\
\hline Liu104 & 4342.98 & $\mathrm{~K}_{1} g_{2}$ & Dolomitic shale & 1.72 & 0.32 & 6.81 & 7.13 & 441 & 396 & 0.1734 & 0.087 & 0.70 \\
\hline Liu104 & 4303.94 & $\mathrm{~K}_{1} g_{2}$ & Shale & 3.10 & 0.54 & 24.71 & 25.25 & 441 & 797 & 0.2987 & 0.109 & - \\
\hline Liu104 & 4303.16 & $\mathrm{~K}_{1} g_{2}$ & Shale & 1.80 & 3.76 & 10.92 & 14.68 & 440 & 607 & 1.2528 & 0.603 & 0.62 \\
\hline Liu104 & 4302.40 & $\mathrm{~K}_{1} g_{2}$ & Shale & 1.19 & 0.44 & 1.77 & 2.21 & 432 & 149 & 0.2253 & 0.064 & - \\
\hline Liu104 & 4245.59 & $\mathrm{~K}_{1} g_{3}$ & Shale & 3.22 & 0.52 & 22.92 & 23.44 & 442 & 712 & 0.2487 & 0.118 & 0.61 \\
\hline Liu104 & 4243.90 & $\mathrm{~K}_{1} g_{3}$ & Dolomitic shale & 3.28 & 0.82 & 26.63 & 27.45 & 437 & 812 & 0.4434 & 0.156 & - \\
\hline Liu104 & 4242.55 & $\mathrm{~K}_{1} g_{3}$ & Dolomitic shale & 1.51 & 0.50 & 12.63 & 13.13 & 431 & 836 & 0.3059 & 0.088 & 0.60 \\
\hline Liu104 & 4239.13 & $\mathrm{~K}_{1} g_{3}$ & Dolomitic shale & 2.67 & 0.71 & 22.20 & 22.91 & 439 & 831 & 0.3519 & 0.143 & - \\
\hline Liu104 & 4237.02 & $\mathrm{~K}_{1} g_{3}$ & Dolomitic shale & 1.82 & 0.47 & 9.31 & 9.78 & 433 & 512 & 0.2098 & 0.072 & 0.62 \\
\hline
\end{tabular}

The units are as follows. 1: TOC, \%; $2: S_{1}, \mathrm{mg} \mathrm{HC} / \mathrm{g}$ rock; $3: S_{2}, \mathrm{mg} \mathrm{HC} / \mathrm{g}$ rock; 4: $S_{1}+S_{2}, \mathrm{mg} \mathrm{HC/g}$ rock; 5: $T_{\max },{ }^{\circ} \mathrm{C} ; 6: \mathrm{HI}, \mathrm{mg} \mathrm{HC} / \mathrm{g} \mathrm{TOC} ; 7:$ extract, \%; 8: HC, \%; 9: $R_{\mathrm{o}}, \%$

chromatograph was equipped with an HP-5MS elastic silica capillary column $60 \mathrm{~m}$ in length, $0.25 \mathrm{~mm}$ in radius, and $0.25 \mu \mathrm{m}$ in film thickness. Helium $(99.999 \%)$ was used as the carrier gas; the temperature of injection port was $300^{\circ}$ $\mathrm{C}$ and the transmission line temperature was also $300^{\circ} \mathrm{C}$; the column temperature was programmed from the initial $50{ }^{\circ} \mathrm{C}$ (hold on $1 \mathrm{~min}$ ) to $200{ }^{\circ} \mathrm{C}$ at $20^{\circ} \mathrm{C} / \mathrm{min}$, to $250^{\circ} \mathrm{C}$ at $4{ }^{\circ} \mathrm{C} / \mathrm{min}$, and then to $300{ }^{\circ} \mathrm{C}$ (hold on $30 \mathrm{~min}$ ) at $3{ }^{\circ} \mathrm{C} / \mathrm{min}$; and the flow rate of carrier gas was $1 \mathrm{~mL} / \mathrm{min}$. The mass spectrometer was operated in EI mode at an ionization voltage of $1047 \mathrm{~V}$.

\subsection{X-ray diffraction (XRD) and vitrinite reflectance $\left(R_{0}\right)$ of source rock}

In total, 21 source rock samples were selected for X-ray diffraction analysis, and 18 source rock samples were analyzed for vitrinite reflectance. The whole rock X-ray 


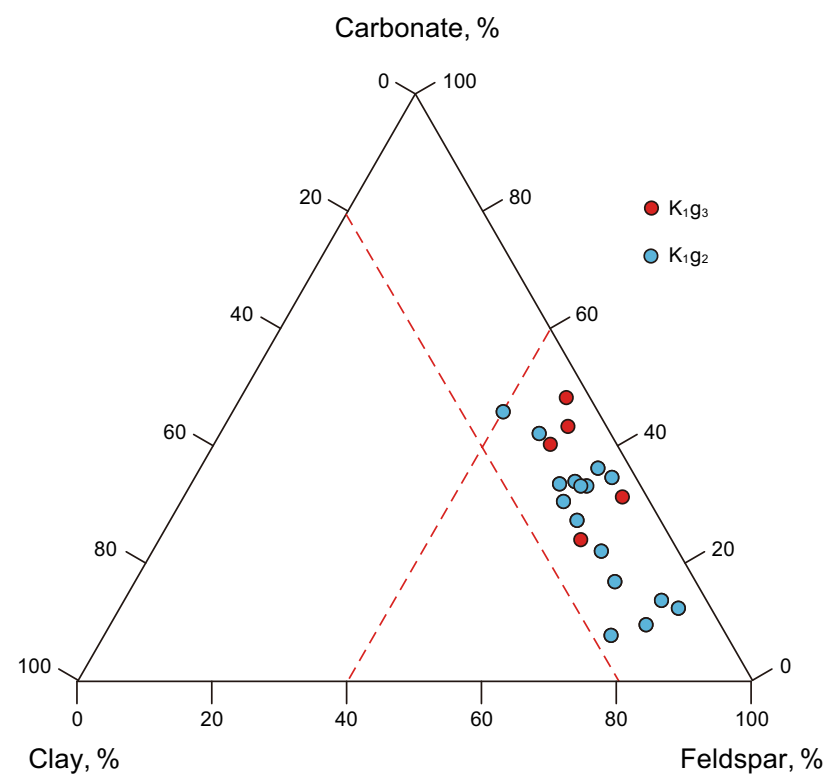

Fig. 2 Ternary plot of mineral components of the Xiagou Formation source rocks of the Qingxi Sag, Jiuquan Basin

diffraction (XRD) analysis for mineral composition was performed on a Bruker D2 PHASER diffractometer system using $\mathrm{Cu} \mathrm{Ka}$ radiation at $30 \mathrm{kV}$ and $10 \mathrm{~mA}$. The powders were scanned over a sampling range of $5-60^{\circ} 2 \theta(\theta$ is the diffraction angle) with a step of $0.01^{\circ} 2 \theta$ and a scan speed of $2 \mathrm{~s}$ per step. The analytical precision is about $4 \%(2 \mathrm{~s}$, standard deviation). The vitrinite reflectance $\left(R_{\mathrm{o}}\right)$ values of 18 bulk rock samples were tested by using an MPV-SP microscope photometer.

All of the experimental tests were carried out in State Key Laboratory of Petroleum Resource and Prospecting of China University of Petroleum, Beijing. Apart from the above-mentioned analysis of collected samples, the other analytical testing of source rocks such as TOC, Rock-Eval parameters, and $R_{\mathrm{o}}$ was undertaken at the Research Institute of Exploration and Development of Yumen Oilfield Company.

\section{Results}

The mineral composition data for the 21 source rock samples analyzed by XRD analysis are shown in Table 1. The TOC, TS, bitumen extract, HC content values, the Rock-Eval pyrolysis data for the 37 source rock samples, and the $R_{\mathrm{o}}$ data for the 18 source rock samples are shown in Table 2. The statistical parameters for the saturated fraction from the Xiagou Formation source rocks are given in Table 4, and the statistical parameters for saturated fraction, terpane, and sterane from the Xiagou Formation source rocks are shown in Table 5.

\section{Discussion}

\subsection{Mineral composition of source rocks}

Mineral composition of sedimentary rock is controlled by many factors including material source, transport distance, hydrodynamic conditions, the sedimentary environment, and diagenesis (Soleimani and Zamani 2015). From Table 1, it can be observed that the mineral components in the source rocks include mainly potassium feldspar, plagioclase, dolomite, clay, and a small quantity of quartz, calcite, pyrite, and anhydrite (Table 1). There is more plagioclase than potassium feldspar in the source rocks, and their contents vary between $27 \%$ and $74 \%$ (averaging $50 \%$ ) and between $0 \%$ and $19 \%$ (averaging 6\%), respectively. In carbonate minerals, the dolomite is dominate and the calcite can hardly be detected, and their contents vary between $7 \%$ and $45 \%$ (averaging 27\%) and between $0 \%$ and $2 \%$ (averaging $0.3 \%$ ), respectively. The clay mineral has medium contents ranging from $3 \%$ to $15 \%$ (averaging $8 \%$ ). The contents of quartz, pyrite, and anhydrite vary from $1 \%$ to $7 \%$ (averaging $3 \%$ ), $0 \%$ to $5 \%$ (averaging $1.4 \%$ ), and $0 \%$ to $7 \%$ (averaging $4 \%$ ), respectively. The existence of anhydrite and dolomite minerals indicates that

Table 3 Statistical data of TOC, bitumen extract, HC, and Rock-Eval parameters in different members of the Xiagou Formation source rocks

\begin{tabular}{lllllllll}
\hline Member & TOC & $S_{1}+S_{2}$ & Extract & HC & $S_{1}$ & $S_{2}$ & $T_{\max }$ \\
\hline $\mathrm{K}_{1} g_{3}$ & $0.31-3.33$ & $0.11-27.45$ & $0.009-0.452$ & $0.003-0.231$ & $0.01-8.2$ & $0.05-26.63$ & $380-735$ & $10-930$ \\
& $1.23(196)$ & $5.42(189)$ & $0.166(26)$ & $0.077(26)$ & $0.45(185)$ & $4.98(189)$ & $438(189)$ & $354(187)$ \\
$\mathrm{K}_{1} g_{2}$ & $0.51-3.1$ & $0.60-25.25$ & $0.050-1.253$ & $0.018-0.603$ & $0.08-3.76$ & $0.52-24.71$ & $424-448$ & $75-797$ \\
& $1.32(107)$ & $5.20(98)$ & $0.228(22)$ & $0.101(21)$ & $0.40(98)$ & $4.77(99)$ & $438(99)$ & $318(99)$ \\
$\mathrm{K}_{1} g_{1}$ & $0.17-6.89$ & $0.07-36.06$ & $0.004-1.631$ & $0.001-0.91$ & $0.02-9.8$ & $0.05-32.54$ & $424-458$ & $16-706$ \\
& $1.56(328)$ & $6.51(317)$ & $0.201(35)$ & $0.105(35)$ & $0.86(317)$ & $5.65(317)$ & $439(317)$ & $304(317)$ \\
$\mathrm{K}_{1} g_{0}$ & $0.85-11.53$ & $1.97-16.09$ & $0.062-0.365$ & $0.029-0.219$ & $0.11-2.9$ & $1.86-14.61$ & $436-452$ & $24-631$ \\
& $2.36(64)$ & $7.08(64)$ & $0.161(4)$ & $0.095(4)$ & $1.09(64)$ & $5.99(64)$ & $443(64)$ & $259(64)$ \\
\hline
\end{tabular}

The units are as follows. 1: TOC, $\% ; 2: S_{1}+\mathrm{S}_{2}, \mathrm{mg} \mathrm{HC} / \mathrm{g}$ rock; 3: extract, $\% ; 4: \mathrm{HC}, \% ; 5: S_{1}, \mathrm{mg} \mathrm{HC} / \mathrm{g}$ rock; $6: S_{2}, \mathrm{mg} \mathrm{HC} / \mathrm{g}$ rock; $7: T_{\max },{ }^{\circ} \mathrm{C}$; 8: HI, mg HC/g TOC. Data of the table are minimum-maximum and average/sample number. The statistical data in the table include the tested data of this time and the collected data 

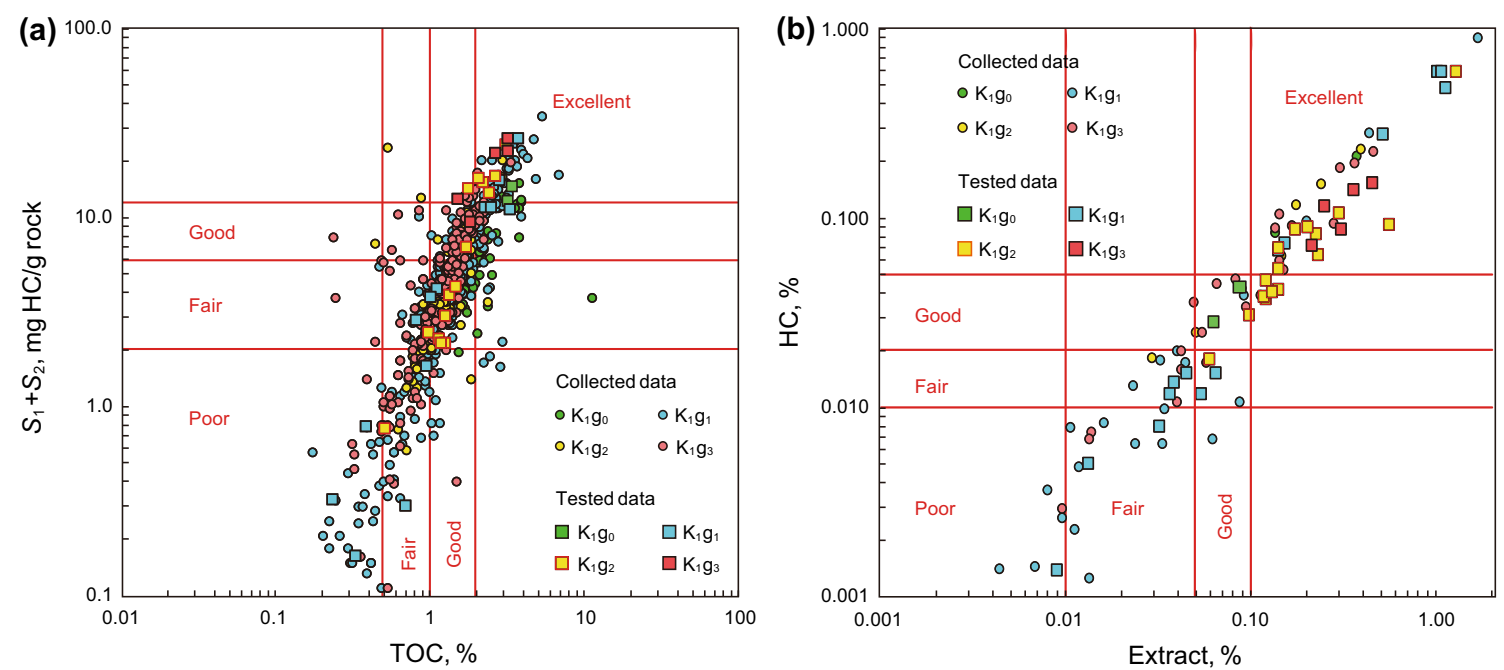

Fig. 3 Cross diagrams of TOC versus $S_{1}+S_{2}$ (a) and bitumen extract versus HC (b) for the Xiagou Formation source rock samples

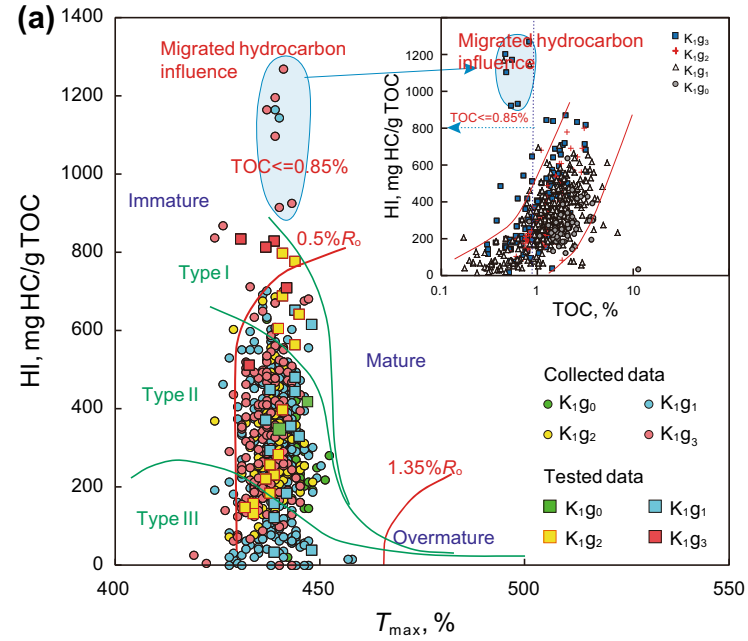

Fig. 4 Cross diagrams of $T_{\max }$ versus HI (a) and TOC versus $S_{2}$ (b) for the Xiagou Formation source rocks. a The organic matter-type boundary line according to Sadettin Korkmaz et al. (2013); b source rock quality boundary representing oil- and gas-prone attribute after

the Xiagou Formation source rock was formed in an alkaline sedimentary environment (Kuang et al. 2012; Li et al. 2014), and the appearance of pyrite indicates that the Xiagou Formation source rock was formed in a reducing environment (Berner 1984). Therefore, the above-mentioned analyses indicate that the Xiagou Formation source rock was formed in a closed and reducing alkaline sedimentary environment. In the ternary plot of carbonates, feldspars, and clay minerals, the feldspar minerals are the most abundant, the carbonate minerals are the second, and the clay minerals are the least (Fig. 2). These source rocks with high abundance of brittle minerals (carbonates and feldspars, etc.) are easily fractured under the action of

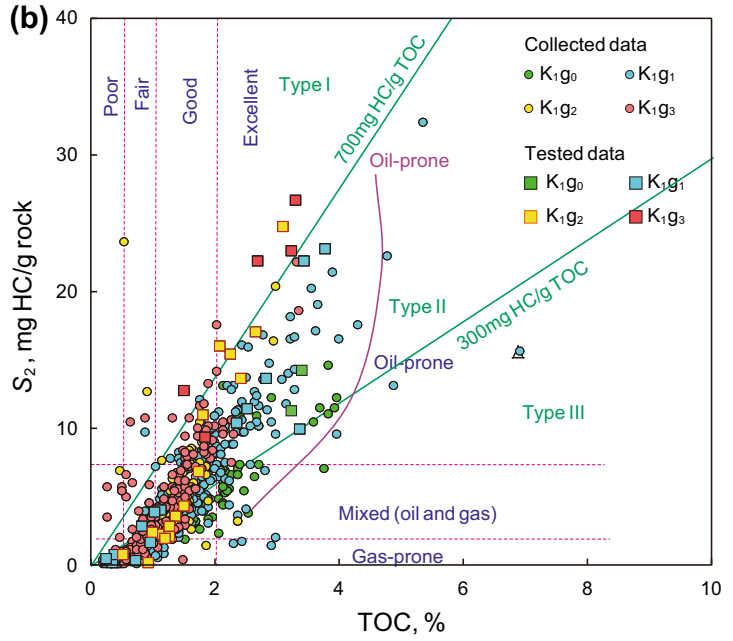

Hakimi et al. (2010); border between Type II/III organic matter (300 mg HC/g TOC) after Langford and Blanc-Valleron (1990), border between Type I/II organic matter (700 mg HC/g TOC) after Espitalié et al. (1985)

tectonic stress. This is consistent with the existence of fracture reservoirs in the Qingxi Sag (Cheng et al. 2007; Wang et al. 2008).

\subsection{Organic matter richness}

Organic matter $(\mathrm{OM})$ is fundamental to hydrocarbon generation in source rocks (Tissot and Welte 1984), and generally, four parameters (TOC, extract, $\mathrm{HC}$, and $S_{1}+S_{2}$ ) are used to evaluate organic matter abundance of source rock (Cheng et al. 2007). In the Qingxi Sag, the organic matter abundances of the Xiagou Formation source rocks are higher (Tables 2, 3). The TOC contents of the $\mathrm{K}_{1} g_{3}, \mathrm{~K}_{1} g_{2}$, 

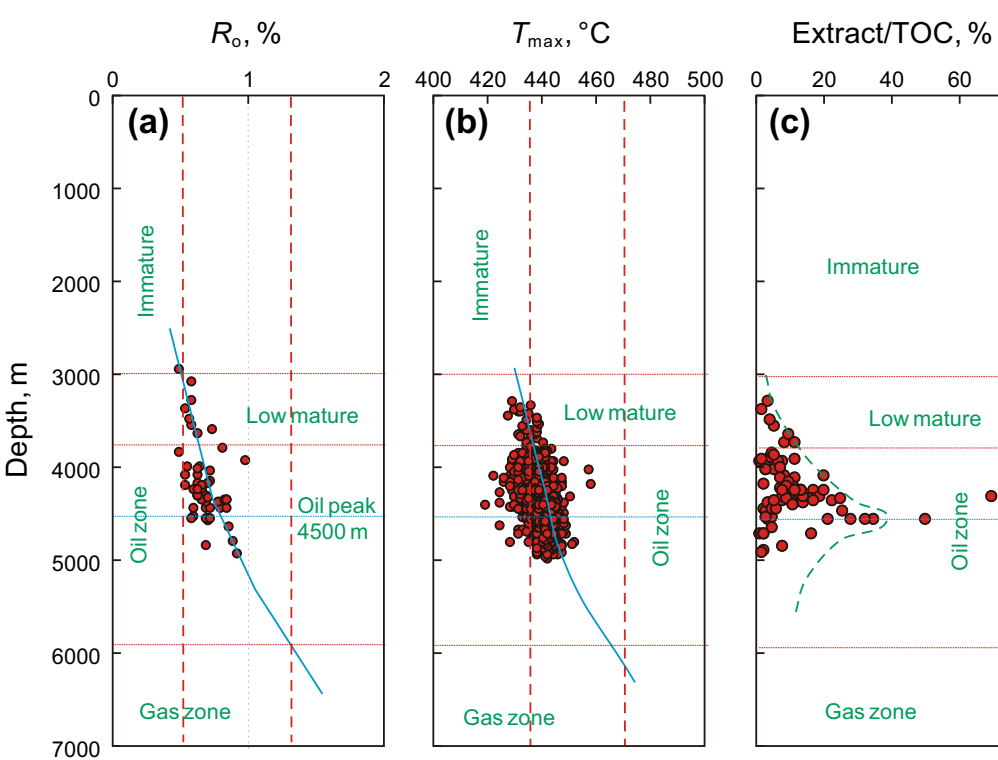

$S_{1} /\left(S_{1}+S_{2}\right)$

$\mathrm{HCl}, \mathrm{mg} \mathrm{HC} / \mathrm{g} \mathrm{TOC}$
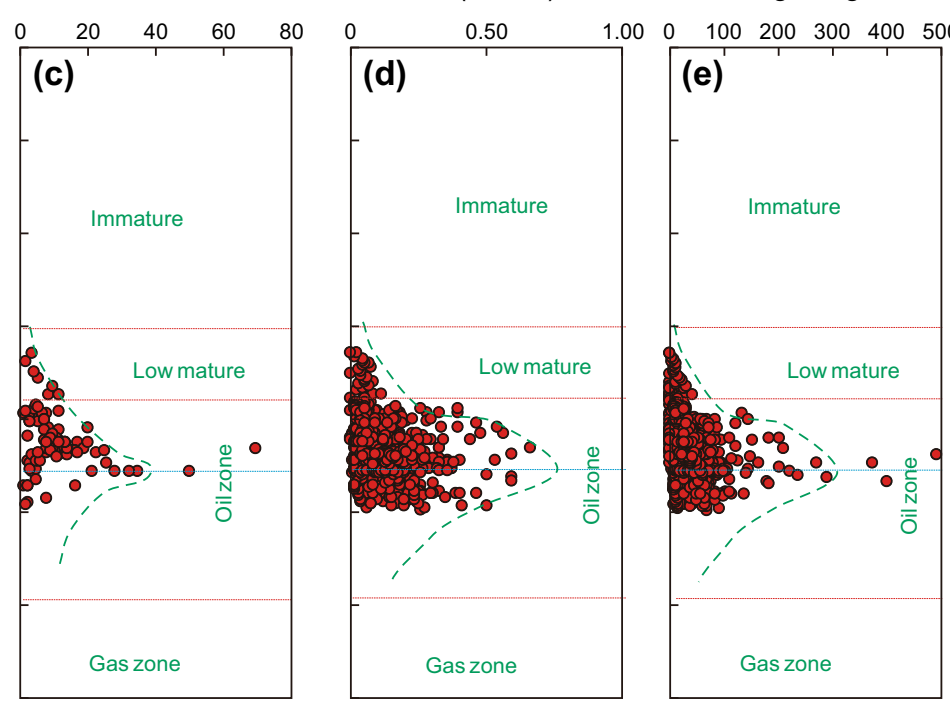

Fig. 5 Diagrams of $R_{\mathrm{o}}, T_{\max }$, extract/TOC, $S_{1} /\left(S_{1}+S_{2}\right)$, and HCI versus depth for the Xiagou Formation source rocks in the Qingxi Sag, Jiuquan Basin

$\mathrm{K}_{1} g_{1}$, and $\mathrm{K}_{1} g_{0}$ source rocks vary from $0.31 \%$ to $3.33 \%$ (average: $1.23 \%$ ), $0.51 \%$ to $3.1 \%$ (average: $1.32 \%$ ), $0.17 \%$ to $6.89 \%$ (average: $1.56 \%$ ), and $0.85 \%$ to $11.53 \%$ (average: $2.36 \%$ ), respectively, and the $S_{1}+S_{2}$ values vary from 0.11 to $27.4 \mathrm{mg} \mathrm{HC} / \mathrm{g}$ rock (average: $5.42 \mathrm{mg} \mathrm{HC} / \mathrm{g}$ rock), 0.6 to $25.2 \mathrm{mg} \mathrm{HC} / \mathrm{g}$ rock (average: $5.2 \mathrm{mg} \mathrm{HC} / \mathrm{g}$ rock), 0.07 to $36.1 \mathrm{mg} \mathrm{HC} / \mathrm{g}$ rock (average: $6.51 \mathrm{mg} \mathrm{HC} / \mathrm{g}$ rock), and 1.97 to $16.1 \mathrm{mg} \mathrm{HC} / \mathrm{g}$ rock (average: $7.08 \mathrm{mg} \mathrm{HC} / \mathrm{g}$ rock), respectively (Tables 2, 3). As shown in Fig. 3a, different members of the Xiagou Formation contain a great amount of fair to excellent source rocks (Huang et al. 1984; Cheng 1994).

Extract contents of the $\mathrm{K}_{1} g_{3}, \mathrm{~K}_{1} g_{2}, \mathrm{~K}_{1} g_{1}$, and $\mathrm{K}_{1} g_{0}$ source rocks range from $0.0094 \%$ to $0.452 \%$ (average: $0.166 \%$ ), $0.050 \%$ to $1.253 \%$ (average: $0.228 \%$ ), $0.0044 \%$ to $1.631 \%$ (average: $0.200 \%$ ), $0.0621 \%$ to $0.365 \%$ (average: $0.162 \%$ ), respectively, and their $\mathrm{HC}$ contents vary from $0.0030 \%$ to $0.231 \%$ (average: $0.077 \%$ ), $0.0181 \%$ to $0.603 \%$ (average: $0.101 \%$ ), $0.0013 \%$ to $0.91 \%$ (average: $0.105 \%$ ), and $0.0285 \%$ to $0.211 \%$ (average: $0.0946 \%$ ), respectively (Tables 2, 3). As shown in Fig. 3b, most source rock samples of the $\mathrm{K}_{1} g_{3}, \mathrm{~K}_{1} g_{2}, \mathrm{~K}_{1} g_{1}$, and $\mathrm{K}_{1} g_{0}$ fall in the fair-excellent source rock zone.

Based on the above-mentioned analyses, there are large amounts of high-quality source rocks distributed in the different members of the Xiagou Formation.

\subsection{Organic matter type}

The organic matter type determines the oil-prone/gas-prone property of source rock (Salah and Alsharhan 1997; Alsharhan 2003). The $S_{2}$ and HI parameters of Rock-Eval pyrolysis are often used to evaluate the organic matter type of source rock (Espitalié et al. 1985; Langford and BlancValleron 1990; Hakimi et al. 2010; Korkmaz et al. 2013). In the study area, the $S_{2}$ values range from 0.01 to $32.5 \mathrm{mg}$ $\mathrm{HC} / \mathrm{g}$ rock (average: $5.36 \mathrm{mg} \mathrm{HC} / \mathrm{g}$ rock), and the $\mathrm{HI}$ has a wide scope between 1.4 and $1680 \mathrm{mg} \mathrm{HC} / \mathrm{g}$ TOC (average: $329 \mathrm{mg} \mathrm{HC} / \mathrm{g}$ TOC) (Table 3; Fig. 4a). Some samples show HI values more than $900 \mathrm{mg} / \mathrm{g}$ TOC, but they have lower TOC contents (Fig. 4a). It is speculated that these samples are possible to be influenced by migrated hydrocarbon (Gao et al. 2016). Figure 4a, b indicates that there are the most Type II organic matter and some Type III and Type I in the source rocks. According to statistical results, the HI values of the $\mathrm{K}_{1} g_{3}, \mathrm{~K}_{1} g_{2}, \mathrm{~K}_{1} g_{1}$, and $\mathrm{K}_{1} g_{0}$ source rocks range from 28 to $869 \mathrm{mg} \mathrm{HC/g}$ TOC, 75 to $797 \mathrm{mg} \mathrm{HC/g}$ TOC, 23 to $706 \mathrm{mg} \mathrm{HC/g} \mathrm{TOC,} \mathrm{and} 24$ to $631 \mathrm{mg} \mathrm{HC/g}$ TOC with an average of $350,318,307$, and $259 \mathrm{mg} \mathrm{HC} / \mathrm{g}$ TOC, respectively (Table 3). It can be observed that the HI values of the $\mathrm{K}_{1} g_{3}, \mathrm{~K}_{1} g_{2}, \mathrm{~K}_{1} g_{1}$, and $\mathrm{K}_{1} g_{0}$ source rocks gradually decrease (Table 3 ). This should be related to their gradually increasing maturity. This indicates that organic matter-type distributions of the $\mathrm{K}_{1} g_{3}, \mathrm{~K}_{1} g_{2}, \mathrm{~K}_{1} g_{1}$, and $\mathrm{K}_{1} g_{0}$ source rocks are similar, and all of them have stronger oilprone properties in the study area.

\subsection{Thermal maturation}

The vitrinite reflectance $\left(R_{\mathrm{o}}\right)$ and Rock-Eval parameter are applied to assess thermal evolution for source rock (Peters et al. 2005). In the study area, the tested $R_{\mathrm{O}}$ values for the source rock vary from $0.49 \%$ to $0.98 \%$ (averaging $0.67 \%$ ), and the $T_{\max }$ values range between 426 and $452{ }^{\circ} \mathrm{C}$ 

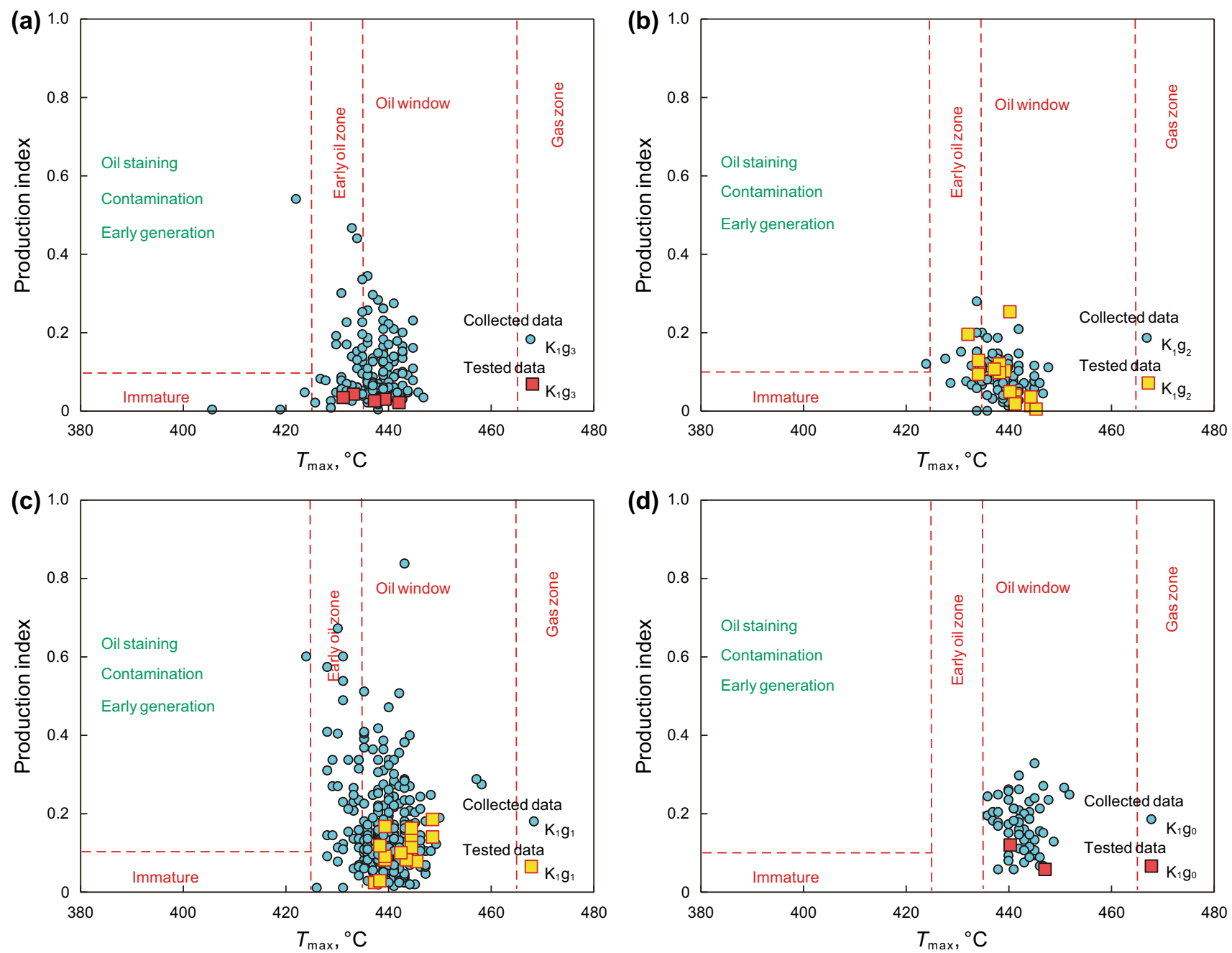

Fig. 6 Cross plots of $T_{\max }$ versus $S_{1} /\left(S_{1}+S_{2}\right)$ for the Xiagou Formation source rocks in the Qingxi Sag (after Peters et al. 1986)

(averaging $439^{\circ} \mathrm{C}$ ) (Table 3). In Fig. 5a, b, both the $R_{\mathrm{o}}$ and the $T_{\max }$ values have an increasing trend with increasing depth, and the inferred low maturity $\left(R_{\mathrm{o}}=0.5 \%-0.7 \%\right)$ depth interval is about $3000-3800 \mathrm{~m}$, the mature source rock is mainly below about $3800 \mathrm{~m}$ depth with an oil peak depth of $4500 \mathrm{~m}$ (corresponding $R_{\mathrm{o}}$ is about $0.8 \%$ ), and the bottom depth of oil window is not easily determined and is speculated to be about $5900 \mathrm{~m}\left(R_{\mathrm{o}}=1.3 \%\right)$ (Fig. 5a, b). In Fig. $5 \mathrm{c}-\mathrm{e}$, with the increase of depth, the envelop curves of extract/TOC, $S_{1} /\left(S_{1}+S_{2}\right)$, and HCI $\left(S_{1} / \mathrm{TOC}, \mathrm{mg} \mathrm{HC} / \mathrm{g}\right.$ TOC) content values firstly increase and then decrease, and their turning points correspond to an $R_{\mathrm{O}}$ of about $0.8 \%$ and a $T_{\max }$ of about $440{ }^{\circ} \mathrm{C}$. This indicates that the source rock in the Xiagou Formation has generated a great deal of hydrocarbon before the classic oil peak of $R_{\mathrm{O}}=1 \%$ (Tissot and Welte 1984).

The diagrams of $T_{\max }$ versus productive index [PI $=S_{1}$ / $\left.\left(S_{1}+S_{2}\right)\right]$ for the different members of the Xiagou Formation (Fig. 6a-d) show that all of the $\mathrm{K}_{1} g_{0}$ source rock samples fall within the oil window, most of the $\mathrm{K}_{1} g_{1}$ source rock samples are within oil window with a small number in the low maturity stage, while the $\mathrm{K}_{1} g_{2}$ and $\mathrm{K}_{1} g_{3}$ source rock samples fall in the low-mature-mature stages, but they have relatively more samples in the low-mature stage than the $\mathrm{K}_{1} g_{1}$ and $\mathrm{K}_{1} g_{0}$ source rock (Peters et al. 1986). According to Fig. 6, it seems that the samples in $\mathrm{K}_{1} g_{2}$ are much closer to the samples in $\mathrm{K}_{1} g_{1}$, compared with the samples in $\mathrm{K}_{1} g_{3}$.

In the deep Qingxi Sag, the Xiagou Formation reservoirs, having lower porosity and permeability, are typical tight reservoirs (Yang et al. 2004; Sun et al. 2015). Many fractures occur in tight reservoirs of the Xiagou Formation; therefore, the reservoirs of the Xiagou Formation in the Qingxi Sag are typical fractured tight reservoirs (Zhou et al. 2006; Cheng et al. 2007). Figure 7 shows that the $\mathrm{K}_{1} g$ source rocks of the Qingxi Sag experienced two significant stages of uplifting during the Late Cretaceous, Paleocene, and Eocene and secondary burial began in the 


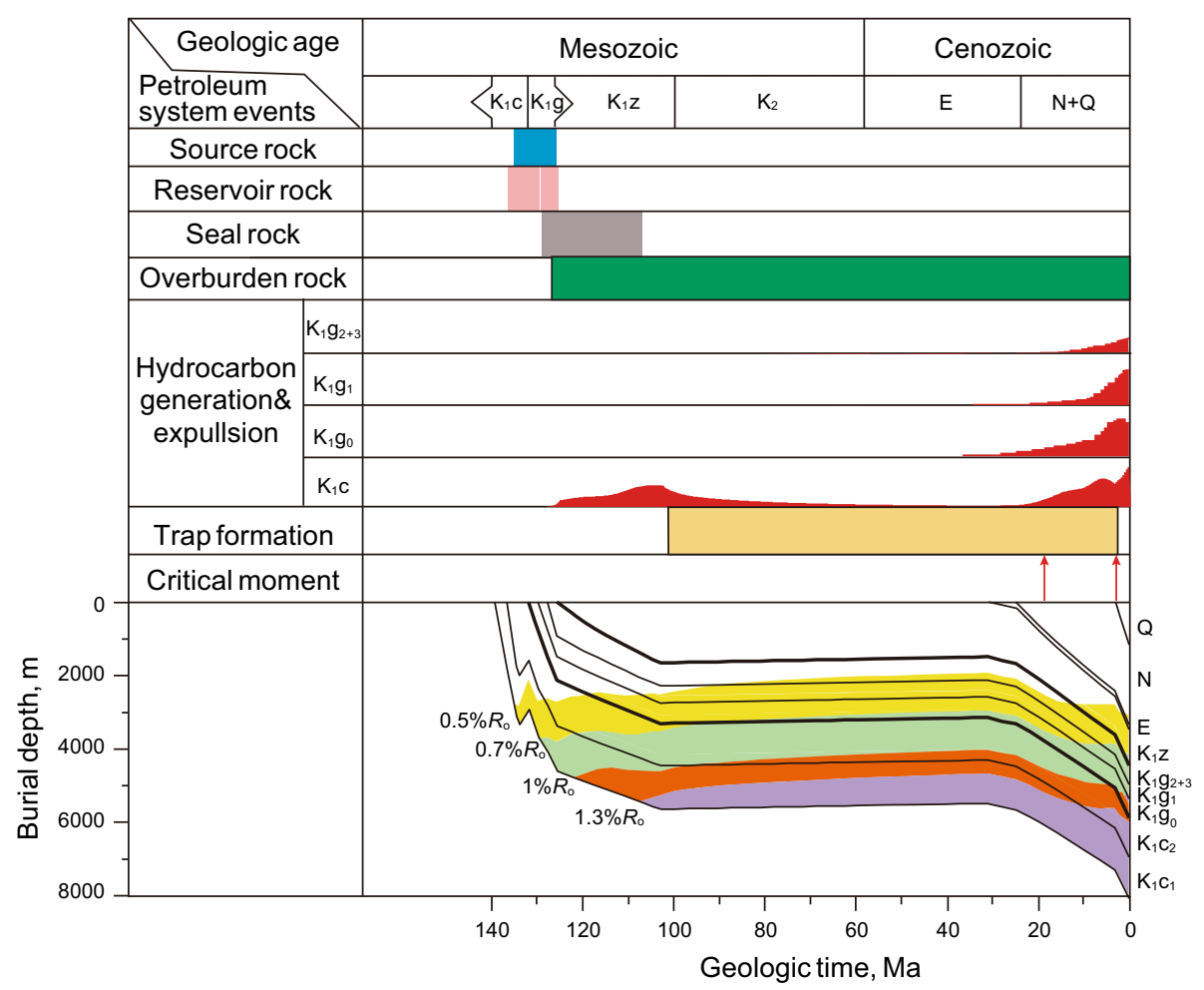

Fig. 7 Hydrocarbon generation and accumulation history of $\mathrm{K}_{1} g$ source rocks in the Qingxi Sag, Jiuquan Basin

Eocene. At present, the Xiagou Formation source rocks of the deep sag are in the stage of oil generation (Fig. 7). The above-mentioned maturity distribution of the Xiagou Formation source rocks shows that the mature source rock tends to be distributed in the older members and greater depth. Therefore, the fractured tight reservoir and mature source rock distributions indicate that there is a better tight oil exploration potential in the deep Qingxi Sag.

\subsection{Saturated fraction geochemistry}

The composition of the saturated hydrocarbon is intimately related to the material source, sedimentary environment, and thermal evolution (Peters et al. 2005). In the study area, $n$-alkanes of the source rock samples range between $n-\mathrm{C}_{11}$ and $n-\mathrm{C}_{35}$, of which the main peak carbon number is $n-\mathrm{C}_{23}$ with a few being $n-\mathrm{C}_{21}$ and $n-\mathrm{C}_{17}$ (Fig. 8). The $\mathrm{C}_{21}$ $\mathrm{C}_{22+}$ ratios of the $\mathrm{K}_{1} g_{0}, \mathrm{~K}_{1} g_{1}, \mathrm{~K}_{1} g_{2}$, and $\mathrm{K}_{1} g_{3}$ samples have higher values ranging from 1.43 to 1.45 (average: 1.44 ), 0.49 to 7.27 (average: 1.32 ), 0.73 to 2.36 (average: 1.39 ), and 0.93 to 1.26 (average: 1.09), respectively, and their $\left(\mathrm{C}_{27}+\mathrm{C}_{29}+\mathrm{C}_{31}\right) /\left(\mathrm{C}_{15}+\mathrm{C}_{17}+\mathrm{C}_{19}\right)$ ratios are lower from 0.17 to 0.2 (average: 0.19 ), 0.02 to 1.84 (average: 0.57 ), 0.11 to 0.88 (average: 0.38 ), and 0.31 to 0.61 (average: 0.44 ), respectively (Table 4 ). This indicates that aquatic organisms had a greater contribution to the source rocks (Tissot and Welte 1984; Peters et al. 2005). Odd-even- predominance (OEP) and the carbon preference index (CPI) values of the $\mathrm{K}_{1} g_{0}, \mathrm{~K}_{1} g_{1}, \mathrm{~K}_{1} g_{2}$, and $\mathrm{K}_{1} g_{3}$ samples have a greater range. OEP changes from 1.23 to 1.36 (average: 1.3 ), 0.96 to 1.56 (average: 1.25 ), 0.95 to 1.24 (average: 1.09), and 1.01 to 1.24 (average: 1.11), respectively, and the CPI varies from 1.27 to 1.34 (average: 1.31 ), 1.08 to 1.85 (average: 1.43 ), 1.05 to 1.41 (average: 1.17 ), and 1.07 to 1.44 (average: 1.22), respectively (Table 4). The pristane $(\mathrm{Pr})\left(\mathrm{C}_{19}\right)$ and phytane $(\mathrm{Ph})\left(\mathrm{C}_{20}\right)$ contents of the source rock relative to adjacent normal alkanes have larger variations (Fig. 8). The $\mathrm{Pr} / n \mathrm{C}_{17}$ ratio of the $\mathrm{K}_{1} g_{0}$, $\mathrm{K}_{1} g_{1}, \mathrm{~K}_{1} g_{2}$, and $\mathrm{K}_{1} g_{3}$ samples ranges from 0.47 to 0.63 (average: 0.55 ), 0.3 to 3.04 (average: 1.09 ), 0.43 to 1.78 (average: 0.9 ), and 1.62 to 3.41 (average: 2.54 ), respectively; the $\mathrm{Ph} / n \mathrm{C}_{18}$ ratios from 0.58 to 0.58 (average: 0.58 ), 0.3 to 4.7 (average: 1.53 ), 0.62 to 2.14 (average: 1.15 ), and 0.92 to 2.82 (average: 1.93), respectively; and the $\mathrm{Pr} / \mathrm{Ph}$ ratio from 0.86 to 1.06 (average: 0.96 ), 0.2 to 2.29 (average: 0.78 ), 0.64 to 1.23 (average: 0.86 ), and 0.99 to 1.91 (average: 1.44), respectively (Table 4). In Fig. 9, the Pr/n$\mathrm{C}_{17}$ ratio has a roughly positive correlation with the $\mathrm{Ph} / n$ $\mathrm{C}_{18}$ ratios, and the youngest $\mathrm{K}_{1} g_{3}$ has obviously higher $\mathrm{Pr} /$ $n-\mathrm{C}_{17}$ and $\mathrm{Ph} / n-\mathrm{C}_{18}$ ratios than those of the oldest $\mathrm{K}_{1} g_{0}$. This correlation implies that maturity has an influence for the $\mathrm{Pr} / n-\mathrm{C}_{17}$ and $\mathrm{Pr} / n-\mathrm{C}_{18}$ ratios (Dzou et al. 1995; Obermajer et al. 1999). It can be observed that most shale samples fall in the Type II organic matter zone, while only 


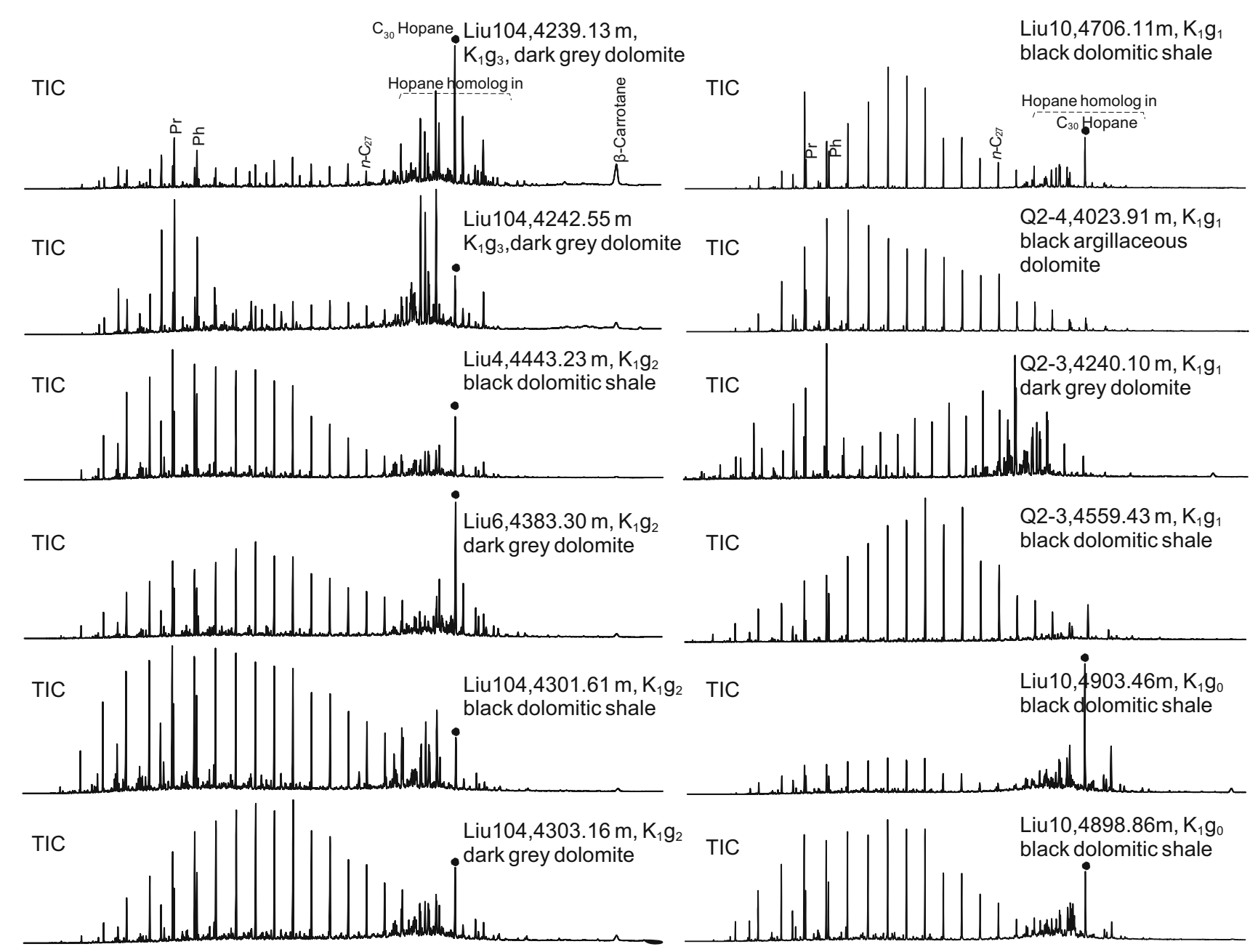

Fig. 8 Examples of total ion current plots of GC-MS for the saturated fractions of the Xiagou Formation source rocks in the Qingxi Sag

Table 4 Statistical data of saturated fraction from the Xiagou Formation source rocks

\begin{tabular}{lllll}
\hline Member & $\mathrm{K}_{1} g_{0}$ & $\mathrm{~K}_{1} g_{1}$ & $\mathrm{~K}_{1} g_{2}$ & $\mathrm{~K}_{1} g_{3}$ \\
\hline $\mathrm{C}_{21-} / \mathrm{C}_{22+}$ & $1.43-1.45$ & $0.49-7.27$ & $0.73-2.36$ & $0.93-1.26$ \\
& $1.44(2)$ & $1.32(14)$ & $1.39(16)$ & $1.09(5)$ \\
$\left(\mathrm{C}_{27}+\mathrm{C}_{29}+\mathrm{C}_{31}\right) /\left(\mathrm{C}_{15}+\mathrm{C}_{17}+\mathrm{C}_{19}\right)$ & $0.17-0.2$ & $0.02-1.84$ & $0.11-0.88$ & $0.31-0.61$ \\
$\mathrm{OEP}$ & $0.19(2)$ & $0.57(14)$ & $0.38(16)$ & $0.44(5)$ \\
& $1.23-1.36$ & $0.96-1.56$ & $0.95-1.24$ & $1.01-1.24$ \\
$\mathrm{CPI}$ & $1.3(2)$ & $1.25(14)$ & $1.09(16)$ & $1.11(5)$ \\
& $1.27-1.34$ & $1.08-1.85$ & $1.05-1.41$ & $1.07-1.44$ \\
$\mathrm{Pr} / n-\mathrm{C}_{17}$ & $1.31(2)$ & $1.43(14)$ & $1.17(16)$ & $1.22(5)$ \\
& $0.47-0.63$ & $0.3-3.04$ & $0.43-1.78$ & $1.62-3.41$ \\
$\mathrm{Ph} / n-\mathrm{C}_{18}$ & $0.55(2)$ & $1.09(14)$ & $0.9(16)$ & $2.54(5)$ \\
& $0.58-0.58$ & $0.3-4.7$ & $0.62-2.14$ & $0.92-2.82$ \\
$\mathrm{Pr} / \mathrm{Ph}$ & $0.58(2)$ & $1.53(14)$ & $1.15(16)$ & $1.93(5)$ \\
& $0.86-1.06$ & $0.2-2.29$ & $0.64-1.23$ & $0.99-1.91$ \\
\hline $\mathrm{CPI}$ & $0.96(2)$ & $0.78(14)$ & $0.86(16)$ & $1.44(5)$ \\
\hline
\end{tabular}

$\mathrm{CPI}=\left[\left(\mathrm{C}_{25}+\mathrm{C}_{27}+\mathrm{C}_{29}+\mathrm{C}_{31}+\mathrm{C}_{33}\right) /\left(\mathrm{C}_{24}+\mathrm{C}_{26}+\mathrm{C}_{28}+\mathrm{C}_{30}+\mathrm{C}_{32}\right)+\left(\mathrm{C}_{25}+\mathrm{C}_{27}+\mathrm{C}_{29}+\mathrm{C}_{31}+\mathrm{C}_{33}\right) /\right.$ $\left.\left(\mathrm{C}_{26}+\mathrm{C}_{28}+\mathrm{C}_{30}+\mathrm{C}_{32}+\mathrm{C}_{34}\right)\right] / 2 ; \mathrm{OEP}=\left(\mathrm{C}_{23}+6 \mathrm{C}_{25}+\mathrm{C}_{27}\right) /\left(4 \mathrm{C}_{24}+4 \mathrm{C}_{26}\right)$ 


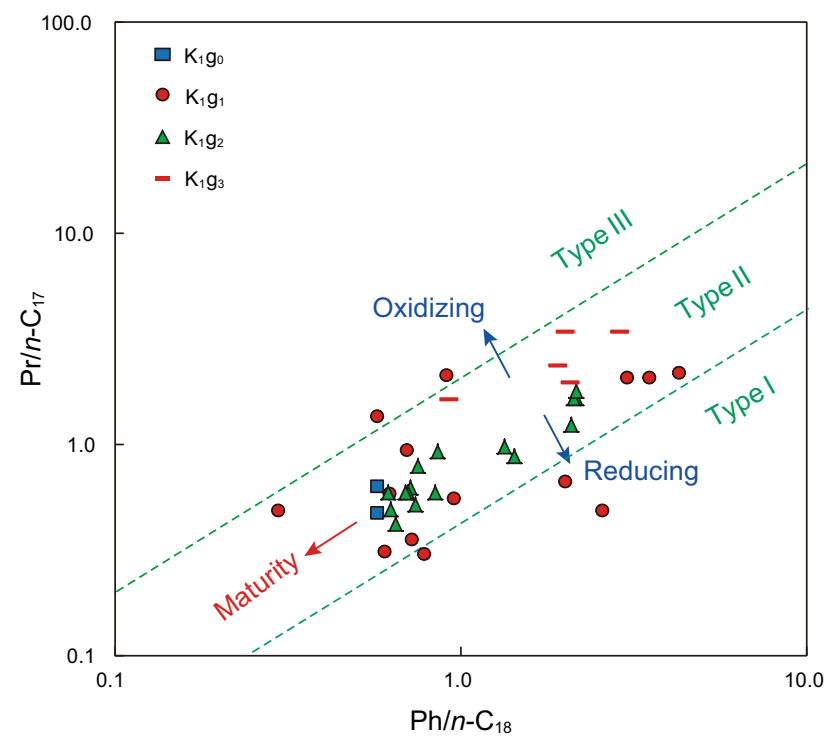

Fig. 9 Genetic characterization of $\mathrm{Pr} / n-\mathrm{C}_{17}$ versus $\mathrm{Ph} / n-\mathrm{C}_{18}$ of the Xiagou Formation source rock extracts [according to the categories of Obermajer et al. (1999)]

a few samples from the $\mathrm{K}_{1} g_{1}$ fall in the Type III and Type I zones (Fig. 9). This indicates that the $\mathrm{K}_{1} g$ source rocks have better oil-generating potential. Moreover, in the TIC plots, carotane can be observed in some samples (Fig. 8). This shows that contribution of algae in anoxic and saline lacustrine water body (Hall and Douglas 1981; Jiang and Flower 1986).

\subsection{Terpanes}

Terpane $(m / z=191)$ distributions of all source rock samples are similar, showing that the tricyclic terpanes are lower than the pentacyclic triterpanes (Fig. 10). The tricyclic terpane abundance increasing with respect to hopane is controlled by thermal maturity and biodegradation (Connan and Cassou 1980; Seifert and Moldowan 1986; Peters et al. 2005), and higher pentacyclic triterpane is associated with bacterial contribution to $\mathrm{OM}$ in the source rocks (Ourisson and Rohmer 1992; Montero-Serrano et al. 2010). The tricyclic/pentacyclic terpane ratios of the Xiagou Formation source rocks range between 0.03 and 0.06 (average: 0.19) (Table 4). This indicates that thermal maturity of the source rocks is not high and bacterial has contribution to OM (Ourisson and Rohmer 1992; MonteroSerrano et al. 2010).

The tricyclic terpanes range from $\mathrm{C}_{19}$ to $\mathrm{C}_{29}$, with higher $\mathrm{C}_{20}, \mathrm{C}_{21}$, and $\mathrm{C}_{23}$ tricyclic terpanes (Fig. 10). High $\mathrm{C}_{19^{-}}$ $\mathrm{C}_{20}-\mathrm{C}_{21}$ tricyclic terpanes indicate that organic matter derived from a terrestrial origin (Ozcelik and Altunsoy 2005), high $C_{23}$ tricyclic terpane indicates a high contribution of marine matter (Ourisson et al. 1982), and $C_{24}$ tetracyclic terpane was mainly sourced from terrestrial OM input (Philp and Gilbert 1986). Low $\mathrm{C}_{24}$ tetracyclic terpane/ $\mathrm{C}_{23}$ tricyclic terpane reflects reducing conditions (Waples and Machihara 1991). In the Xiagou Formation source rocks, the tricyclic terpane contents are generally low, with the tricyclic/pentacyclic terpane ratios between 0.03 and 0.6 (average: 0.19) (Table 4). The tricyclic/pentacyclic terpane ratios of the $\mathrm{K}_{1} g_{0}, \mathrm{~K}_{1} g_{1}, \mathrm{~K}_{1} g_{2}$, and $\mathrm{K}_{1} g_{3}$ samples vary from 0.07 to 0.1 (average: 0.08 ), 0.03 to 0.6 (average: 0.14 ), 0.14 to 0.41 (average: 0.28 ), and 0.18 to 0.41 (average: 0.26 ), respectively (Table 4). This indicates that the thermal maturity of source rocks is not high and can have bacterial contribution to $\mathrm{OM}$ (Ourisson and Rohmer 1992; Montero-Serrano et al. 2010). The $\mathrm{C}_{21} / \mathrm{C}_{23}$ tricyclic terpane ratios of the $\mathrm{K}_{1} g_{0}, \mathrm{~K}_{1} g_{1}, \mathrm{~K}_{1} g_{2}$, and $\mathrm{K}_{1} g_{3}$ source rocks range from 1.13 to 1.37 (average: 1.25 ), 0.53 to 1.91 (average: 1.28 ), 0.83 to 1.8 (average: 1.29 ), and 1.14 to 1.78 (average: 1.38), respectively, and the $\mathrm{C}_{24}$ tetracyclic/ $\mathrm{C}_{23}$ tricyclic terpane ratios range from 0.82 to 0.94 (average: 0.88 ), 0.26 to 7.25 (average: 1.36 ), 0.22 to 1.67 (average: 0.6 ), and 0.25 to 1.08 (average: 0.59), respectively (Table 5). This indicates that terrigenous higher plants have also contributed to the source rock OM.

The relative abundance of $18 \alpha(\mathrm{H})-22,29,30-\mathrm{C}_{27}$ trisnorneohopane (Ts) to $17 \alpha(\mathrm{H})-22,29,30-\mathrm{C}_{27}$ trisnorhopane $(\mathrm{Tm})$ ratio is used as maturity indicator, for Ts has a greater stability than $\mathrm{Tm}$ and increases with increasing maturation; therefore, $\mathrm{Ts} / \mathrm{Tm}$ ratio rises with increasing thermal maturation; however, this ratio is controlled by the sedimentary environment (Peters et al. 2005). The Ts/Tm ratios for the $\mathrm{K}_{1} g_{0}, \mathrm{~K}_{1} g_{1}, \mathrm{~K}_{1} g_{2}$, and $\mathrm{K}_{1} g_{3}$ samples vary from 0.29 to 0.56 (average: 0.42 ), 0.01 to 1.56 (average: 0.29 ), 0.01 to 0.26 (average: 0.19 ), and 0.13 to 0.52 (average: 0.25 ), respectively. This indicates that source rocks are mainly in the early-mature to mature stage. The $\mathrm{C}_{30}$ diahopane abundance is related to clay-rich, oxic-anoxic depositional environments (Peters et al. 2005), and its abundance increases with increasing maturity (Kolaczkowska et al. 1990). The $C_{30}$ diahopane/ $C_{30}$ hopane ratios are lower between 0.003 and 0.081 for all of the source rock samples (Table 5). This indicates that the source rocks of the $\mathrm{K}_{1} g_{0}$, $\mathrm{K}_{1} g_{1}, \mathrm{~K}_{1} g_{2}$, and $\mathrm{K}_{1} g_{3}$ were formed in an anoxic depositional environment.

The gammacerane abundance is mainly related to water salinity (Moldowan et al. 1986; Mello et al. 1988; Ten Haven et al. 1988). The source rocks from the $\mathrm{K}_{1} g_{0}, \mathrm{~K}_{1} g_{1}$, $\mathrm{K}_{1} g_{2}$, and $\mathrm{K}_{1} g_{3}$ contain higher gammacerane, with their gammacerane/ $\mathrm{C}_{30}$ hopane ratios varying from 0.29 to 0.4 (average: 0.35 ), 0.03 to 0.72 (average: 0.18 ), 0.16 to 0.49 (average: 0.29 ), and 0.27 to 0.79 (average: 0.47 ), respectively (Table 5). Figure 11 shows that most of the Xiagou Formation source rock samples fall in the zone of anoxic to suboxic depositional environment with a stratified water 


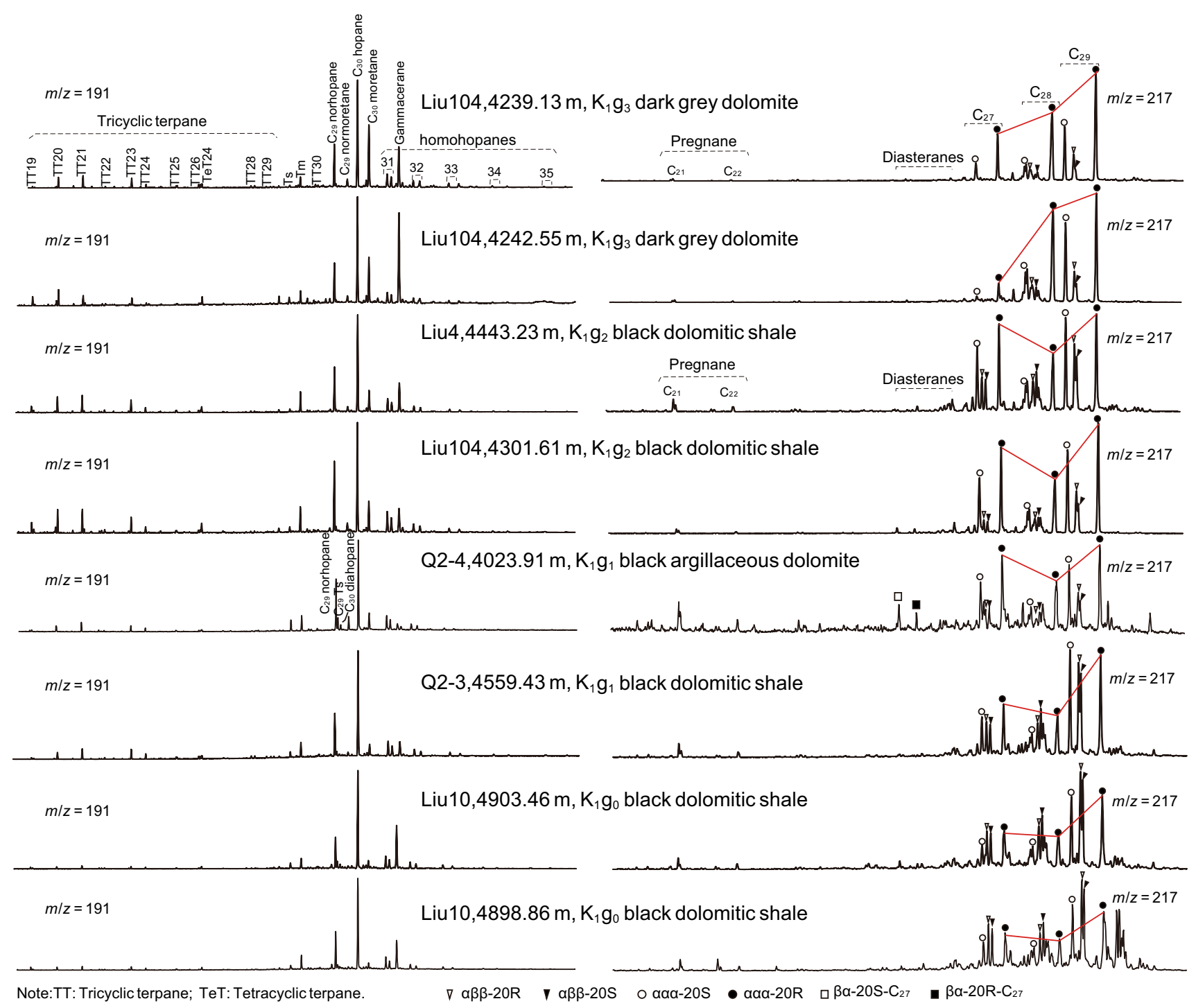

Fig. 10 Examples of the $m / z=191$ and $m / z=217$ fragmentograms of some saturated fractions of the Xiagou Formation source rocks

column or possibly enhanced water salinity, with some samples of the $\mathrm{K}_{1} g_{1}$ in the zone of anoxic to suboxic depositional environment with normal lacustrine water or no stratification.

\subsection{Steranes}

Steranes are generally used to assess the source and maturity of OM in source rock (Peters and Moldowan 1993; Peters et al. 2005). The relative abundance of regular steranes $\mathrm{C}_{27}, \mathrm{C}_{28}$, and $\mathrm{C}_{29}$, is often used to determine the dominant source of $\mathrm{OM}$ since $\mathrm{C}_{27}, \mathrm{C}_{28}$, and $\mathrm{C}_{29}$ sterols derive mainly from zooplankton, phytoplankton, and land plants, respectively (Huang and Meinschein 1979). The $\mathrm{C}_{29} / \mathrm{C}_{27}$ sterane ratios of the $\mathrm{K}_{1} g_{0}, \mathrm{~K}_{1} g_{1}, \mathrm{~K}_{1} g_{2}$, and $\mathrm{K}_{1} g_{3}$ source rock samples vary from 1.71 to 2.08 (average: 1.9), 0.36 to 23.08 (average: 2.3 ), 1.13 to 2.55 (average: 1.63 ), and 2.02 to 5.97 (average: 3.53 ), respectively, and the $\mathrm{C}_{28}$ / $\mathrm{C}_{29}$ ratios change from 0.42 to 0.49 (average: 0.46 ), 0.23 to 0.74 (average: 0.52 ), 0.41 to 0.75 (average: 0.57 ), and 0.48 to 0.85 (average: 0.67 ), respectively (Table 5). In Fig. 12a, all of the samples from the $\mathrm{K}_{1} g_{0}, \mathrm{~K}_{1} g_{2}$, and $\mathrm{K}_{1} g_{3}$ and most samples from the $\mathrm{K}_{1} g_{1}$ fall in the planktonic/land plant zone, with a few of samples from the $\mathrm{K}_{1} g_{1}$ in the planktonic/algal zone. This indicates that the OM of the Xiagou Formation source rocks came chiefly from planktonic and land plant organisms, with the OM of part of the source rocks from plankton, and algal and bacterial organisms (Adegoke et al. 2014). Diagrams of $\mathrm{Pr} / \mathrm{Ph}$ ratio versus $\alpha \alpha \alpha$ $20 \mathrm{R}-\mathrm{C}_{29} / \mathrm{C}_{27}$ ratio are applied to analyze OM source and redox condition (Mei and Liu 1980; McKenzie et al. 1981). In Fig. 12b, the samples from the $\mathrm{K}_{1} g_{0}$ and $\mathrm{K}_{1} g_{3}$ fall in the land plant zone with reducing fresh water, and the samples of the $\mathrm{K}_{1} g_{1}$ and $\mathrm{K}_{1} g_{2}$ fall in the algal zone and the land 
Table 5 Biomarker parameters of four members of the Xiagou Formation

\begin{tabular}{lllll}
\hline Formation & $\mathrm{K}_{1} g_{0}$ & $\mathrm{~K}_{1} g_{1}$ & $\mathrm{~K}_{1} g_{2}$ & $\mathrm{~K}_{1} g_{3}$ \\
\hline Tricyclic/pentacyclic terpane & $0.07-0.1$ & $0.03-0.6$ & $0.14-0.41$ & $0.18-0.41$ \\
& $0.08(2)$ & $0.14(14)$ & $0.28(16)$ & $0.26(5)$ \\
$\mathrm{C}_{21} / \mathrm{C}_{23}$ tricyclic terpane & $1.13-1.37$ & $0.53-1.91$ & $0.83-1.8$ & $1.14-1.78$ \\
& $1.25(2)$ & $1.28(14)$ & $1.29(16)$ & $1.38(5)$ \\
$\mathrm{C}_{24}$ tetracyclic terpane/C ${ }_{23}$ tricyclic terpane & $0.82-0.94$ & $0.26-7.25$ & $0.22-1.67$ & $0.25-1.08$ \\
& $0.88(2)$ & $1.36(14)$ & $0.6(16)$ & $0.59(5)$ \\
Ts/Tm & $0.29-0.56$ & $0.01-1.56$ & $0.01-0.26$ & $0.13-0.52$ \\
& $0.42(2)$ & $0.29(14)$ & $0.19(16)$ & $0.25(5)$ \\
$\mathrm{C}_{30} *$ diahopane/C 30 & $0.014-0.038$ & $0.004-0.081$ & $0.003-0.015$ & $0.006-0.011$ \\
$\mathrm{Gammacerane}_{30} / \mathrm{C}_{30}$ hopane & $0.026(2)$ & $0.026(14)$ & $0.011(16)$ & $0.008(5)$ \\
$20 \mathrm{R}-\alpha \alpha \alpha-\mathrm{C}_{29} / \mathrm{C}_{27}$ sterane & $0.29-0.4$ & $0.03-0.72$ & $0.16-0.49$ & $0.27-0.79$ \\
& $0.35(2)$ & $0.18(14)$ & $0.29(16)$ & $0.47(5)$ \\
$20 \mathrm{R}-\alpha \alpha \alpha-\mathrm{C}_{28} / \mathrm{C}_{29}$ sterane & $1.71-2.08$ & $0.36-23.08$ & $1.13-2.55$ & $2.02-5.97$ \\
& $1.89(2)$ & $2.3(14)$ & $1.63(16)$ & $3.53(5)$ \\
$\mathrm{C}_{29} 20 \mathrm{~S} /(20 \mathrm{~S}+20 \mathrm{R})$ sterane & $0.42-0.49$ & $0.23-0.74$ & $0.41-0.75$ & $0.48-0.85$ \\
$\mathrm{C}_{29} \beta \beta /(\alpha \alpha+\beta \beta)$ sterane & $0.46(2)$ & $0.52(14)$ & $0.57(16)$ & $0.67(5)$ \\
& $0.49-0.51$ & $0.28-0.53$ & $0.39-0.49$ & $0.3-0.42$ \\
& $0.5(2)$ & $0.43(14)$ & $0.44(16)$ & $0.36(5)$ \\
& $0.56-0.58$ & $0.15-0.54$ & $0.2-0.39$ & $0.2-0.27$ \\
& $0.57(2)$ & $0.32(14)$ & $0.27(16)$ & $0.23(5)$ \\
\hline
\end{tabular}

more land plant input. In addition, some of the source rock samples contain some $\mathrm{C}_{30}$ steranes (Fig. 10). This further indicates that there are some algal contributions in the source rocks (Fu et al. 1985; Brassell et al. 1986; Zan et al. 2012).

The $\mathrm{C}_{29} 20 \mathrm{~S} /(20 \mathrm{~S}+20 \mathrm{R})$ and $\mathrm{C}_{29} \beta \beta /(\beta \beta+\alpha \alpha)$ sterane ratios are applied to evaluate maturation of source rock OM (Peters and Moldowan 1993), and with increasing maturity, they increase until equilibrium of 0.55 and 0.7 , respectively (Peters et al. 2005). In the study area, the $\mathrm{C}_{29}$ 20S/ $(20 \mathrm{~S}+20 \mathrm{R})$ sterane ratios of the $\mathrm{K}_{1} g_{0}, \mathrm{~K}_{1} g_{1}, \mathrm{~K}_{1} g_{2}$, and $\mathrm{K}_{1} g_{3}$ range from 0.49 to 0.51 (average: 0.5 ), 0.28 to 0.53 (average: 0.43 ), 0.39 to 0.49 (average: 0.44 ), and 0.3 to 0.42 (average: 0.36), respectively, and the $C_{29} \beta \beta /(\alpha \alpha+\beta \beta)$ sterane ratios range from 0.56 to 0.58 (average: 0.57 ), 0.15 to 0.54 (average: 0.32 ), 0.2 to 0.39 (average: 0.27 ), and 0.2 to 0.27 (average: 0.23 ), respectively (Table 5 ). This indicates that the source rocks are mainly in the low-mature to mature stage. In Fig. 13, it can be observed that the $\mathrm{K}_{1} g_{0}$ source rock samples are in the mature stage, the $\mathrm{K}_{1} g_{3}$ samples are mainly low maturity, the $\mathrm{K}_{1} g_{2}$ samples are mainly low mature with a small number mature, and the $\mathrm{K}_{1} g_{1}$ samples have a wide maturation range from low-mature to mature stages. Therefore, the $\mathrm{K}_{1} g_{0}$ and $\mathrm{K}_{1} g_{1}$ contain a great amount of mature source rocks and should have more prospects for oil reservoirs in the deep sag. plant zone with both reducing fresh water and heavily reducing salt water. It can be concluded that the Xiagou Formation source rock was formed in a favorable sedimentary environment for oil source rock, the $\mathrm{K}_{1} g_{1}$ and the $\mathrm{K}_{1} g_{2}$ source rocks have alternative algal and land plant input, and the $\mathrm{K}_{1} g_{0}$ and $\mathrm{K}_{1} g_{3}$ source rocks have relatively 


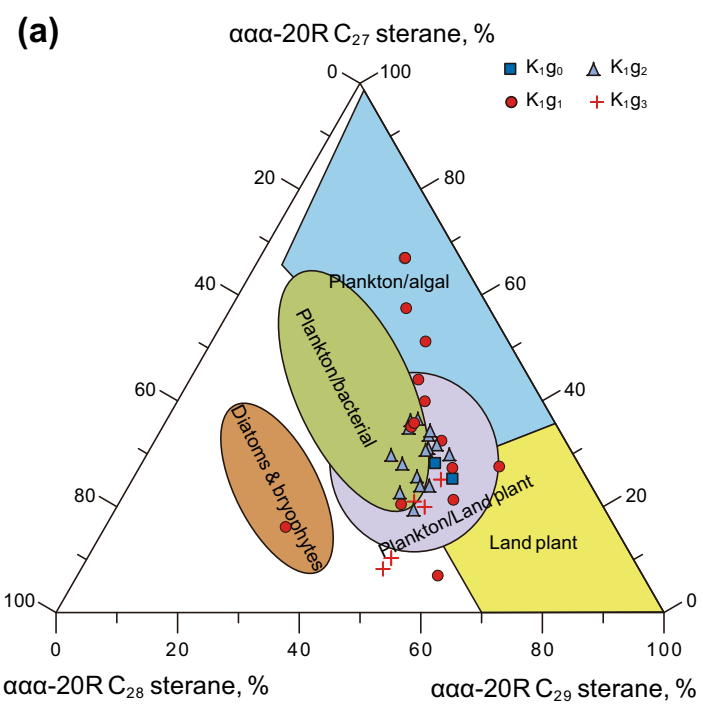

Fig. 12 Ternary plot of regular steranes $\left(\mathrm{C}_{27}, \mathrm{C}_{28}\right.$, and $\left.\mathrm{C}_{29}\right)(\mathrm{a})$ and diagram of $\mathrm{Pr} / \mathrm{Ph}$ versus $\alpha \alpha \alpha-20 \mathrm{R}-\mathrm{C}_{27} / \mathrm{C}_{29}$ ratio (b) of the Xiagou Formation source rocks. a Shows the relationship between sterane composition and organic matter input in the Xiagou Formation

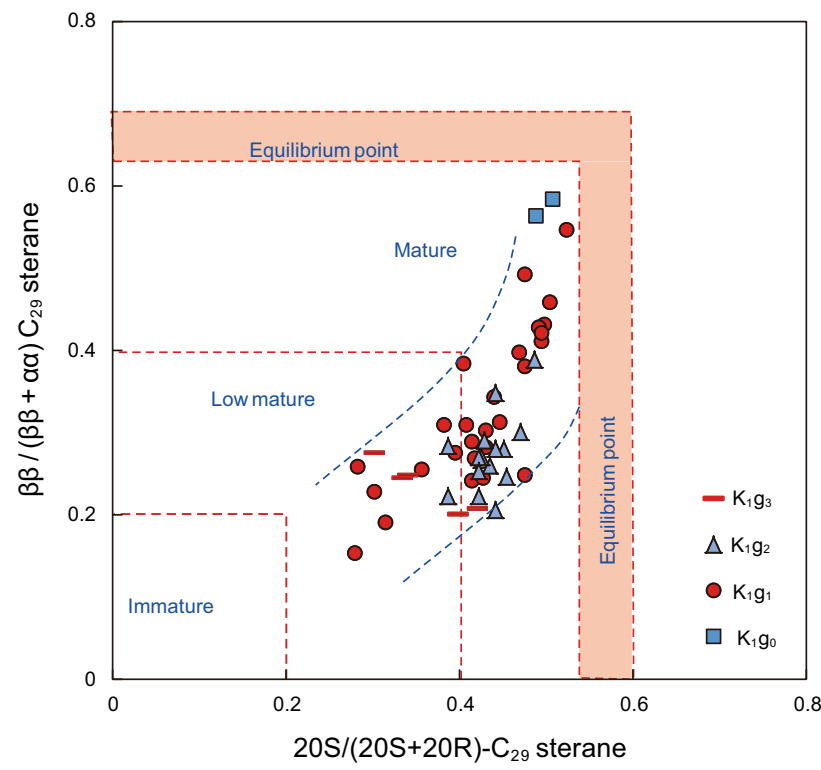

Fig. 13 Cross diagram of the $20 \mathrm{~S} /(20 \mathrm{~S}+20 \mathrm{R})-\mathrm{C}_{29}$ sterane ratio and the $\beta \beta /(\alpha \alpha+\beta \beta)-C_{29}$ sterane ratio of the Xiagou Formation source rocks, the equilibrium scope after Peters et al. (2005)

\section{Conclusions}

The existing research for the Lower Cretaceous Xiagou Formation source rocks in Qingxi Sag of the Jiuquan Basin is scattered. The current study systematically analyzes the mineral composition and organic geochemistry of the Cretaceous Xiagou Formation source rocks, and it suggests the following major conclusions:

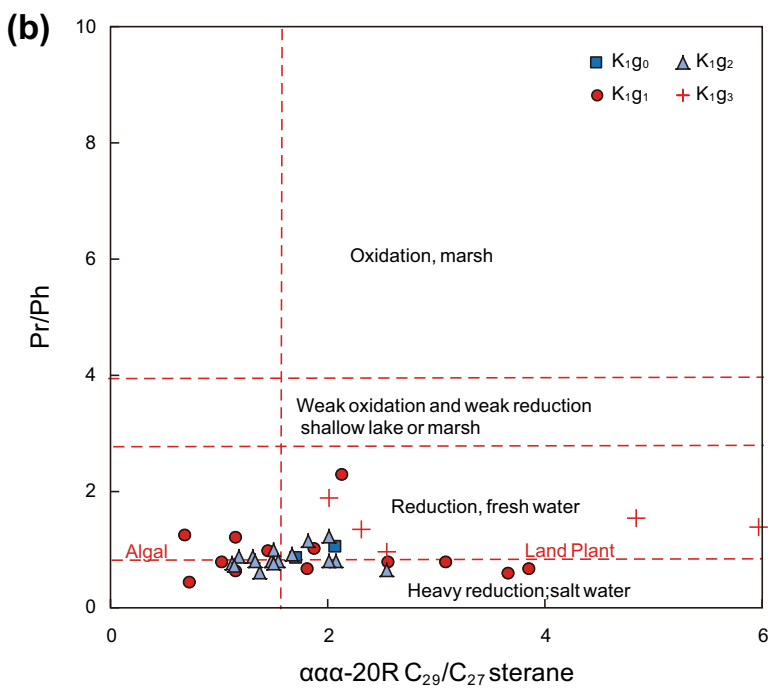

[modified after Adegoke et al. (2014)]; b shows relation of organic matter input and depositional condition, $\mathrm{Pr} / \mathrm{Ph}$ ratio standard line according to Mei and Liu (1980), and $\alpha \alpha \alpha-20 \mathrm{R} \quad \mathrm{C}_{29} / \mathrm{C}_{27}$ sterane standard line according to McKenzie et al. (1981)

Mineral composition and biological marker analyses show that the Xiagou Formation source rock was formed in a closed, reducing, anoxic, and alkaline lacustrine environment with higher salinity, with more brittle minerals which are favorable for fracture reservoirs within source rock formations in the Qingxi Sag. According to analyses of TOC, Rock-Eval pyrolysis, extract, and HC, there are a great number of fair to excellent source rocks distributed in the Xiagou Formation.

TOC, Rock-Eval pyrolysis, and biomarker analyses suggest that the Xiagou Formation source rocks mainly contain OM coming from plankton/algae and higher plants as well as possible bacteria organisms, and its $\mathrm{OM}$ is mainly Type II and part of Type III and I, and they have a stronger oil generation potential.

The Xiagou Formation source rocks are mainly in the early-mature to mature stage, and $R_{\mathrm{o}}$ value corresponding to its oil peak is lower than classic oil peak $R_{\mathrm{O}}$ value $(0.8 \%)$. This indicates that the source rock of the Xiagou Formation has generated a great deal of hydrocarbon before the classic oil peak of $R_{\mathrm{o}}=1 \%$.

The mature source rock in the Xiagou Formation tends to be distributed in the older members and at greater depth. This indicates that there is a better tight oil exploration potential in the deep Qingxi Sag.

Acknowledgements This study was supported by the Fourth Petroleum Resource Evaluation Project of China (Grant No. 2013E050209) and the National S\&T Major Project of China (Grant No. 2012E330). We acknowledge the Petroleum Exploration and Development Research Institute of the Yumen Oil Field Company for allowing the publication of the manuscript, and in particular, they 
have provided part of the well data, stratigraphic framework, and a great amount of test data from the source rocks for us.

Open Access This article is distributed under the terms of the Creative Commons Attribution 4.0 International License (http://crea tivecommons.org/licenses/by/4.0/), which permits unrestricted use, distribution, and reproduction in any medium, provided you give appropriate credit to the original author(s) and the source, provide a link to the Creative Commons license, and indicate if changes were made.

\section{References}

Adegoke AK, Abdullah WH, Hakimi MH, Yandoka BMS. Geochemical characterisation of Fika formation in the Chad (Bornu) Basin, northeastern Nigeria: implications for depositional environment and tectonic setting. Appl Geochem. 2014;43:1-12. https://doi.org/10.1016/j.apgeochem.2014.01.008.

Alsharhan AS. Petroleum geology and potential hydrocarbon plays in the Gulf of Suez rift basin, Egypt. AAPG Bull. 2003;87:143-80. https://doi.org/10.1306/062002870143.

Berner RA. Sedimentary pyrite formation: an update. Geochim Cosmochim Acta. 1984;48:605-15. https://doi.org/10.1016/ 0016-7037(84)90089-9.

Brassell SC, Eglinton G, Fu JM. Biological marker compounds as indicators of depositional history of the Maoming oil shale. Org Geochem. 1986;10:927-41. https://doi.org/10.1016/S0146-6380 (86)80030-4

Chen JJ, Fan MT, Tao GL, Han YK, Wang CX. Application of new ideas and new techniques to find oil and old oil fields bloomthe petroleum exploration and practice the in the western Jiuquan Basin. China Pet Explor. 2001;6(3):15-20. https://doi.org/10. 3969/j.issn.1672-7703.2001.03.003 (in Chinese).

Cheng KM. Oil and gas generation of the Tuha Basin. Beijing: Petroleum Industry Press; 1994 (in Chinese).

Cheng KM, Xiong Y, Ma LY. The Kulongshan and Liugouzhuang Oil reservoir: a kind of source rock fractured reservoir of the Qingxi Sag in Jiuxi Depression. Acta Sedimentol Sin. 2007;25(3):4616. https://doi.org/10.14027/j.cnki.cjxb.2007.03.019 (in Chinese).

Connan L, Cassou AM. Properties of gases and petroleum liquids derived from terrestrial kerogen at various maturation levels. Geochim Cosmochim Acta. 1980;44:1-23. https://doi.org/10. 1016/0016-7037(80)90173-8.

Dzou LI, Noble RA, Senftle JT. Maturation effects on absolute biomarker concentration in a suite of coals and associated vitrinite concentrates. Org Geochem. 1995;23:681-97. https:// doi.org/10.1016/0146-6380(95)00035-D.

Espitalié J, Deroo G, Marquis F. La Pyrolyse Rock-Eval et ses Applications. Revue de L'Institut Francais du Pétrole. 1985;40:560-579-755-784. https://doi.org/10.2516/ogst: 1985045.

Fan MT, Yang ZM, Tian BZ, Yue ZZ, Li T. Genesis of viscous crude and asphalt of Qingxi Oilfield in Jiuquan Basin, Northwest China. Pet Explor Dev. 2004;31(1):40-1. https://doi.org/10. 3321/j.issn:1000-0747.2004.01.011 (in Chinese).

Fu JM, Xu FF, Chen DY. Biomarker compounds of biological inputs in Maoming oil shale. Geochimica. 1985;14(2):99-114 (in Chinese).

Gao G, Zhang WW, Xiang BL, Liu GD, Ren JL. Geochemistry characteristics and hydrocarbon-generating potential of lacustrine source rock in Lucaogou Formation of the Jimusaer Sag, Junggar Basin. J Pet Sci Eng. 2016;145:168-82. https://doi.org/ 10.1016/j.petrol.2016.03.023.
Hakimi MH, Abdullah WH, Shalaby MR. Source rock characterization and oil generating potential of the Jurassic Madbi Formation, onshore East Shabowah oil elds, Republic of Yemen. Org Geochem. 2010;41:513-21. https://doi.org/10.1016/j.orggeo chem.2009.12.011.

Hall PB, Douglas AG. The distribution of cyclic alkanes in two lacustrine deposits. In: Hjoray M, Albrecht C, Cornford C, et al., editors. Advances in organic geochemistry. Chichester: Wiley; 1981. p. 576-87.

Han YK, Hu Y, Wang CX, Yang ZM. The differences between two oil-enriched sags and their exploration prospects in Jiuquan Basin. Xinjiang Pet Geol. 2007;28(1):691-3. https://doi.org/10. 3969/j.issn.1001-3873.2007.06.008 (in Chinese).

Huang WY, Meinschein WG. Sterols as ecological indicators. Geochim Cosmochim Acta. 1979;43:739-45. https://doi.org/10. 1016/0016-7037(79)90257-6.

Huang DF, Li JC, Gu XZ. Evolution and hydrocarbon-generating mechanisms of terrigenous organic matter. Beijing: Petroleum Industry Press; 1984 (in Chinese).

Hudec MR, Jackson MPA. Advance of allochthonous salt sheets in passive margins and orogens. AAPG Bull. 2006;90(10):153564. https://doi.org/10.1306/05080605143.

Jiang ZS, Flower MG. Carotenoid derived alkanes in oil from Northwestern China. Org Geochem. 1986;10:831-9. https://doi. org/10.1016/s0146-6380(86)80020-1.

Jin Q, Zha M, Zhao L. Identification of effective source rocks in the tertiary evaporate facies in the western Qaidam Basin. Acta Sedimentol Sin. 2001;19(1):125-9. https://doi.org/10.14027/j. cnki.cjxb.2001.01.022 (in Chinese).

Kolaczkowska E, Slougui NE, Watt DS, Marcura RE, Moldowan JM. Thermodynamic stability of various alkylated, dealkylated, and rearranged $17 \alpha$ and $17 \beta$-hopane isomers using molecular mechanics calculations. Org Geochem. 1990;16:1033-8. https://doi.org/10.1016/0146-6380(90)90140-U.

Korkmaz S, Kara-Gülbay R, Haluk Iztan Y. Organic geochemistry of the Lower Cretaceous black shales and oil seep in the Sinop Basin, Northern Turkey: an oil-source rock correlation study. Mar Pet Geol. 2013;43:272-83. https://doi.org/10.1016/j.marpet geo.2013.02.003.

Kuang LC, Tang Y, Lei DW, Chang QS, Ouyang M, Hou LH, et al. Formation conditions and exploration potential of tight oil in the Permian saline lacustrine dolomitic rock, Junggar Basin, NW China. Pet Explor Dev. 2012;39(6):657-67. https://doi.org/10. 1016/s1876-3804(12)60095-0.

Langford FF, Blanc-Valleron MM. Interpreting Rock-Eval pyrolysis data using graphs of pyrolizable hydrocarbons vs. total organic carbon. AAPG Bull. 1990;74:799-804. OSTI Identifier: 6305406.

Li W, Liu B, Lv T. Oil source discussion of Laojunmiao structure belt in the west Jiuquan Basin. Pet Explor Dev. 2005;30(2):30-2. https://doi.org/10.3321/j.issn:1000-0747.2003.02.007 (in Chinese).

Li T, Yang KR, Han XS, Jiang YX. Analysis on controlling factors of Cretaceous lithologic reservoirs in Yaxi area of Jiuquan Basin. Lithol Reserv. 2010;22(Supplement issue):20-5. https://doi.org/ 10.3969/j.issn.1673-8926.2010.z1.004 (in Chinese).

Li XP, Du JY, Ding L, Liu J, Chen WT, Chen SH, et al. Origin of mineral series of anhydrite-limonite-kaolinite-dolomite and its paleoclimate significance: an example from Zhujiang Formation of Well LH-3 in eastern Pearl River Mouth Basin. J Jilin Univ Earth Sci Edn. 2014;44(1):213-21. https://doi.org/10.13278/j. cnki.jjuese.201401117 (in Chinese).

Ma LY, Cheng KM, Liu DM, Xiong Y. Distribution characteristics of algae laminae in the Xiagou Formation and its relationship with hydrocarbons in Jiuquan Basin. Sedimentol Acta. 2007;25 
(1):147-52. https://doi.org/10.3969/j.issn.1000-0550.2007.01. 019 (in Chinese).

Ma SP, Zhang XB, Ma LY, Sang TY. The kerogen geochemistry characteristics of the Lower Crataceous lacustrine source rock in Kulongshan structure of Qingxi Sag, west Jiuquan Basin. J Oil Gas Technol. 2009;31(2):233-6 (in Chinese).

Ma SP, Sun D, Zhang XB, Xia YQ. The Study of hydrocarbon generation kinetics in Lower Cretaceous lacustrine source rocks, Qingxi Depression, Jiuxi Basin. Natl Gas Geosci. 2011;22 (2):219-23 (in Chinese).

McKenzie AS, Hoffmann CF, Maxwell JR. Molecular parameters of maturation in the Toarcian shales, Paris Basin, France-Ill. Changes in aromatic steroid hydrocarbons. Geochim Cosmochim Acta. 1981;45:1345-55. https://doi.org/10.1016/0016-7037(81) 90227-1.

Mei BW, Liu XJ. The distribution of isoprenoid alkanes in China's crude oil and its relation with the geologic environment. Oil Gas Geol. 1980;1(2):99-115. https://doi.org/10.11743/ogg19800203 (in Chinese).

Mello MR, Telnaes N, Gaglianone PC, Chicarelli MI, Brassel SC, Maxwell JR. Organic geochemical characterization of depositional environments of source rocks and oils in Brazilian marginal basins. Org Geochem. 1988;13:31-45. https://doi.org/ 10.1016/b978-0-08-037236-5.50009-9.

Moldowan JM, Sundararaman P, Schoell M. Sensitivity of biomarker properties to depositional environment and/or source input in the Lower Toarcian of S.W. Germany. Org Geochem. 1986;10:91526. https://doi.org/10.1016/s0146-6380(86)80029-8.

Montero-Serrano JC, Martínez M, Riboulleau A, Tribovillard N, Márquez G, Gutiérrez-Martín JV. Assessment of the oil sourcerock potential of the Pedregoso Formation (Early Miocene) in the Falcón Basin of northwestern Venezuela. Mar Pet Geol. 2010;27:1107-18. https://doi.org/10.1016/j.marpetgeo.2009.12. 007.

Obermajer M, Fowler MG, Snowdon LR. Depositional environment and oil generation in Ordovician source rocks from southwestern Ontario, Canada: organic geochemical and petrological approach. AAPG Bull. 1999;83:1426-53. https://doi.org/10. 1306/e4fd41d9-1732-11d7-8645000102c1865d.

Ourisson G, Rohmer M. Hopanoids. 2. Biohopanoids: a novel class of bacterial lipids. Acc Chem Res. 1992;25:403-8. https://doi.org/ 10.1021/ar00021a004

Ourisson G, Albrecth P, Rohmer M. Predictive microbial biochemistry from molecular fossils to procaryotic membranes. Trends Biochem Sci. 1982;7:236-9. https://doi.org/10.1016/0968-0004 (82)90028-7.

Ozcelik O, Altunsoy M. Organic geochemical characteristics of Miocene bituminous units in the Beypazari Basin, Central Anatolia, Turkey. Arab J Sci Eng. 2005;30:181-94. https://doi. org/10.1144/1354-079302-564.

Pan LY, Sun X, Sun XD, Jiao WL. Structural feature and oil/gas accumulation rule in Kulongshan structure of Jiuquan Basin. Oil Geophys Explor. 2007;42(1):115-9. https://doi.org/10.3321/j. issn:1000-7210.2007.01.022 (in Chinese).

Peters KE, The Moldowan J M. Biomarker guide: interpreting molecular fossils in petroleum and ancient sediments. Englewood Cliffs: Prentice-Hall; 1993.

Peters KE, Moldowan JM, Schoell M, Hempkins WB. Petroleum isotopic and biomarker composition related to source rock organic matter and depositional environment. In: Leythaeuser D, Rullkötter J, editors. Advances in organic geochemistry: organic geochemistry. 1985. 10:17-27. https://doi.org/10.1016/01466380(86)90006-9.

Peters KE, Walters CC, Moldowan JM. The biomarker guide. In: Biomarkers and isotopes in petroleum exploration and earth history, Second ed., vol. 2. 2005. Cambridge University Press,
Cambridge: 475-1155. https://doi.org/10.1017/ s0016756806212056.

Philp RP, Gilbert TD. Biomarker distributions in Australian oils predominantly derived from terrigenous source material. Org Geochem. 1986;10:73-84. https://doi.org/10.1016/0146-6380 (86)90010-0.

Salah MG, Alsharhan AS. The Miocene Kareem Formation in the southern Gulf of Suez, Egypt: a review of stratigraphy and petroleum geology. J Pet Geol. 1997;20:327-46. https://doi.org/ 10.1111/j.1747-5457.1997.tb00639.x.

Seifert WK, Moldowan JM. Use of biological markers in petroleum exploration. In: Johns RB, editor. Methods in geochemistry and geophysics. vol. 24. Amsterdam: Elsevier; 1986. p. 261-90.

Soleimani B, Zamani F. Preliminary petroleum source rock evaluation of the Asmari-Pabdeh reservoirs, Karanj and Parsi oil fields, Zagros, Iran. J Pet Sci Eng. 2015;134:97-104. https://doi.org/10. 1016/j.petrol.2015.07.016.

Sun TB, Pan LY, Zhang HW, Zhao JR, Ma GF, Liu YC. Study of tectono-stratigraphic reservoir prospecting in Jiuquan Basin. Oil Geophys Explor. 2006;41(Supplement):37-41. https://doi.org/ 10.3321/j.issn:1000-7210.2006.z1.010 (in Chinese).

Sun WF, Song Y, Gong YJ, Luo Q, Wang CX. The characteristics of Lower Cretaceous Xiagou Formation pelitic dolostone tight oil reservoir, Qingxi sag. Chin J Geol. 2015;50(1):315-29. https:// doi.org/10.3969/j.issn.0563-5020.2015.01.021.

Ten Haven HL, de Leeuw JW, Rullkotter J, Sinninghe-Damste JS. Application of biological markers in the recognition of paleohypersaline environments. In: Fleet AJ, Kelts K, Talbot MR, editors. Lacustrine petroleum source rocks. London: Geological Society Special Publication; 1988. p. 3-26. https://doi.org/10. 1144/gsl.sp.1988.040.01.11.

Tissot BP, Welte DH. Petroleum formation and occurrence. 2nd ed. New York: Springer-Verlag; 1984.

Wang CX, Ma GF, Zhou ZH. Mesozoic-Cenozoic structural evolution and sedimentary filling features. Pet Explor Dev. 2005;32(1):336. https://doi.org/10.3321/j.issn:1000-0747.2005.01.009 (in Chinese).

Wang CX, Tian DW, Wei J, Hang W. Fractures distribution characteristics of Kulongshan reservoir in Jiuquan Basin. Lithol Reserv. 2008;20(4):20-5. https://doi.org/10.3969/j.issn.16738926.2008.04.004 (in Chinese).

Waples D, Machihara T. Biomarkers for geologists, a practical guide to the application of steranes and triterpanes in petroleum geology. AAPG Methods in Exploration Series 9. Tulsa. 1991. https://doi.org/10.1306/99a4d0a6-3318-11d78649000102c1865d.

Xie QM, Li F, Ma CQ. Geological characteristics and distribution of oil and water in Silurian buried hill reservoir in Yaerxia oil field, Jiuxi basin. Spec Oil Gas Reserv. 2001;8(4):5-7. https://doi.org/ 10.3969/j.issn.1006-6535.2001.04.002 (in Chinese).

Yang ZM, Wang Q, Shi JA, Li MR, Wang L. Controls on the enrichment of oil pools in Qingxi Sag, Jiuxi Basin. Acta Sedimentol Sin. 2003;21(4):695-701. https://doi.org/10.3969/j. issn.1000-0550.2003.04.024 (in Chinese).

Yang HM, Wang MF, Yang LK, Wang R, Li YL. Reservoir character of pelitic dolostone in the Xiagou Formation, Lower Cretaceous, Qingxi Oilfield, NW China. Pet Explor Dev. 2004;31(6):47-50. https://doi.org/10.3321/j.issn:1000-0747.2004.06.011

(in Chinese).

You CC, Xiao WH, Fang C. Tectonic characteristic research of Qing Sag in Jiuquan Basin. Sci Technol Assoc Forum. 2011;9(1):1056. https://doi.org/10.3969/j.issn.1007-3973.2011.09.060 (in Chinese).

Zan L, Zhang ZH, Wang SH, Xiong $\mathrm{H}$, Li WH, Liu WN, et al. Application of 4-methyl steranes in oil source correlation-a case study from northern steep slope zone of Bonan Sag. Acta 
Sedimentol Sin. 2012;30(4):770-8. https://doi.org/10.14027/j. cnki.cjxb.2012.04.011 (in Chinese).

Zhao JR, Sun X, Pan LY, Sui TB, Yang GY, Bai J, et al. Integrative evaluation of oil/gas exploration field in Jiuquan Basin. Oil Geophys Explor. 2008;43(1):73-7. https://doi.org/10.13810/j. cnki.issn.1000-7210.2008.s1.029 (in Chinese).
Zhou XF, Zhao YC, Wang CX, Du WB. Research of the fracture reservoir in Qingxi oil field. Xinjiang Geol. 2006;24(1):40-4. https://doi.org/10.3969/j.issn.1000-8845.2006.01.010 Chinese). 